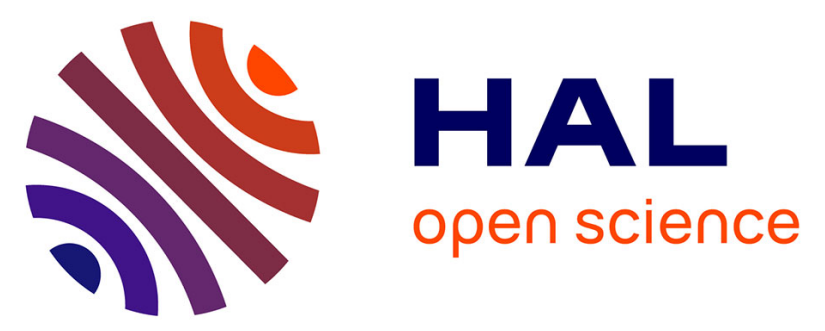

\title{
Relevance of a near infrared spectral index for assessing tillage and fertilization effects on soil water retention
}

Inès Soltani, Youssef Fouad, Didier Michot, P. Pichelin, Christophe Cudennec

\section{To cite this version:}

Inès Soltani, Youssef Fouad, Didier Michot, P. Pichelin, Christophe Cudennec. Relevance of a near infrared spectral index for assessing tillage and fertilization effects on soil water retention. Soil and Tillage Research, 2019, 194 (104345), pp.12. 10.1016/j.still.2019.104345 . hal-02279488

\section{HAL Id: hal-02279488 \\ https://hal.science/hal-02279488}

Submitted on 25 Oct 2021

HAL is a multi-disciplinary open access archive for the deposit and dissemination of scientific research documents, whether they are published or not. The documents may come from teaching and research institutions in France or abroad, or from public or private research centers.
L'archive ouverte pluridisciplinaire HAL, est destinée au dépôt et à la diffusion de documents scientifiques de niveau recherche, publiés ou non, émanant des établissements d'enseignement et de recherche français ou étrangers, des laboratoires publics ou privés.

\section{(ㅇ)(1) $\$$}

Distributed under a Creative Commons Attribution - NonCommerciall 4.0 International 


\section{Relevance of a near infrared spectral index for}

\section{2 assessing tillage and fertilization effects on soil water}

\section{3 retention}

UMR SAS, Agrocampus Ouest, INRA, 35000, Rennes, France

\section{ABSTRACT}

Agricultural practices are expected to have significant effects on soil physical properties, such as soil structure and soil water retention (SWR) properties are among the relevant properties that can be used to assess these effects. Ex-situ measurements are costly and time-consuming. Visible (vis) and near infrared (NIR) spectroscopy has been widely used as a rapid, costeffective and nondestructive technique to predict many soil properties, including soil water content (SWC). In this study, we explored the ability of vis-NIR to assess the effects of soil tillage and fertilization on SWR. The study was performed on silty soil samples with $10.4 \mathrm{~g}$ $\mathrm{kg}^{-1}$ of organic carbon content and a $\mathrm{pH}$ of 5-6.5. Undisturbed soil blocks were collected from an experimental station located in Brittany, France. In 2012, the field was designed as two separate experiments, each with a different tillage system (conventional tillage (CT) and shallow tillage (ST)). For each experiment, two fertilizer types were considered (mineral and organic). Six undisturbed soil blocks were sampled at each of two depths (0-15 cm and 15-25 
treatment (2012) and after 5 years of agricultural practices (2017). From each soil block, four aggregates 3-4 cm wide and 5-6 cm long were collected. The whole aggregates were set at a number of matric potentials, from saturation to the permanent wilting point $(\mathrm{pF}=4.2)$. At a given pressure head, soil samples were scanned in triplicate to acquire reflectance spectra from 400-2500 nm using a handheld spectrometer (ASD Fieldspec®). We focused on the absorption band near $1920 \mathrm{~nm}$ and used a new NIR spectral index based on the band's full width at half maximum, called SWSI. Our results showed a linear relation between SWSI and SWC $\left(\mathrm{R}^{2}>0.99\right)$. Moreover, the slope and intercept of this linear relation were significantly correlated with water holding capacity (WHC) and soil quality. Using these parameters, we found that SWR and soil physical quality under CT were significantly greater under cattle manure (CTC) than under mineral fertilizer (CTM) or at T0. This significant effect was more pronounced at $15-25 \mathrm{~cm}$. In ST treatments, SWR properties and soil quality were significantly lower than at T0. More importantly, our results show that the slope and intercept of the linear relation offer a way to summarize and assess the effects of agricultural practices on SWR properties and soil structural quality.

Keywords: vis-NIR, NIR index, SWSI, soil water retention, soil physical quality, tillage, fertilization. 
Improved soil management techniques require identifying agricultural practices that are environmentally friendly and sustain crop yields. Therefore, there is growing interest in developing systems of shallow tillage (ST) as an alternative to conventional tillage (CT) (Roger-Estrade et al., 2010). CT systems have adverse effects on soil physical, chemical and biological properties and degrade soil ecosystems (IPBES, 2018). They may lead to the breakdown of organic matter, loss of soil moisture and change of water balance, the spread of salinity, increased susceptibility to wind and water erosion, and loss of soil biodiversity (Strudley et al., 2008). Conservation tillage systems, such as no-tillage (NT) and ST, can therefore help protect soil against compaction, erosion and degradation. ST and NT affect soil physical properties, such as bulk density (BD), soil water content (SWC), soil stability (Bottinelli et al., 2017; Czyż and Dexter, 2008; Lipiec et al., 2006; Strudley et al., 2008) and soil physical quality (Dexter, 2004b; Kabiri et al., 2015). However, concern has been expressed that NT crop production could lead to excess soil compaction. Excess compaction may decrease soil aeration and crop root development, thus restricting water uptake, nutrient availability and overall crop growth (Dalal et al., 1991; Lipiec and Nosalewicz, 2004; Mahmoodlu et al., 2016). Compaction can be assessed by BD measurements and soil water retention (SWR) properties.

For agricultural soils, fertilization is also a source of variability for SWR properties both in space and time (Bottinelli et al., 2017; Jiao et al., 2006; Mikha and Rice, 2004). Conventional soil management (i.e. intensive cultivation and the use of synthetic agrochemicals) has often been associated with degraded soil quality, whereas organic farming has been suggested as an approach to conserve and protect the soil environment (Abiven et al., 2009; Maillard and Angers, 2014). Several studies have investigated the differences between organically and conventionally managed soils (Bai et al., 2018; Maillard and Angers, 2014), but few have 
sought to deal with potential differences in SWR properties and soil quality quantitatively in combination with tillage systems.

Accurate assessment of soil properties, traditionally using elemental analysis, is timeconsuming and costly. Hence, sensor techniques are increasingly used to rapidly determine soil properties in the field (Minasny et al., 2014; Tauro et al., 2018). Among them, visible (vis) and near-infrared (NIR) spectroscopy have proven their potential to quickly estimate several soil properties, including particle-size distribution (Gomez et al., 2013; Janik et al., 2009), soil aggregate-size distribution (Cañasveras et al., 2010; Sarathjith et al., 2014), pH (Viscarra Rossel and Behrens, 2010), soil organic carbon (SOC) content (Nocita et al., 2013) and cation-exchange capacity (Soriano-Disla et al., 2014).

Rather than only estimating specific points of the SWR curve, recent studies developed transfer functions for soil hydraulic properties using spectral reflectance data. Using multiple linear regression between soil hydraulic properties and multiple attributes of measured spectral reflectance, Santra et al. (2009) defined transfer functions, called spectrotransfer functions (STFs). They used stepwise regression analysis and principal-componenttransformed spectral data $(350-2500 \mathrm{~nm})$ as well as mimicked Landstat-ETM ${ }^{+}$spectral bands to estimate van Genuchten-Mualem (vGM) soil hydraulic parameters $(\alpha, \mathrm{n}$, and $K s)$ of the wet part of the SWR curve (pressure head $>-80 \mathrm{kPa}$ ). Their results were promising for parameter $\mathrm{n}$, but they failed to estimate parameters $\alpha$ and Ks. A major weakness of this approach is that the soil hydraulic parameters were estimated only from a small range of measured SWC. Other limitations include the use of disturbed soil samples, which usually lose some structural attributes, and the fact that they were collected from topsoil. Thus, the STFs may only be applicable to topsoils. Using spectral data as pedotransfer function (PTF) input provides an effective way of including temporal processes in hydrological models. Babaeian et al. (2015a, 2015b) derived and validated the accuracy of STFs and spectral pedotransfer functions 
(SPTFs) to predict the hydraulic parameters of the vGM SWR model. STFs relate hydraulic vGM parameters directly to spectral reflectance values, while SPTFs use additional basic soil data such as particle-size distribution and BD. The parametric STFs and SPTFs for the vGM model parameters were more accurate at low and intermediate water contents than PTFs, which were more accurate close to saturation. Both STFs and SPTFs estimated the SWR curve with accuracy similar to PTFs.

Recently,Soltani et al. (2019) evaluated the potential of NIR spectroscopy to estimate SWC. They defined a spectral index called the "soil water spectral index" (SWSI), based on the full width at half maximum of the absorption band near $1920 \mathrm{~nm}$. They showed that the SWSI decreases linearly with an increase in SWC. Moreover, they found that the parameters of this linear relation were correlated with soil texture and SOC content. Furthermore, their results indicate that SWSI can be useful for studying how texture and SOC content affect SWR properties, water holding capacity (WHC) and therefore soil structure.

\section{Based on Soltani et al.'s (2019) results, we examined the effectiveness and robustness of the} SWSI in estimating medium-term (five year) impacts of CT and ST, combined with two fertilizer inputs, on SWR properties. We present a comparative analysis of spectral information and soil property data to assess tillage and fertilization impacts on SWR properties and soil physical quality.

\section{Materials and methods}

\section{1. Experimental site and tillage systems}

The study was performed at the EFELE (EFfluents d'ELevage et Environnement) experimental site in Le Rheu, in western France (48 $05^{\prime} 34.94^{\prime \prime}$ N, $1^{\circ} 48^{\prime} 54.27^{\prime \prime}$ W). This field experiment is part of the French "Organic Residues" research observatory (SOERE PRO), which is a network of long-term field experiments on the impacts of organic residue 
application in agriculture (more information on SOERE PRO and EFELE is available at www6.inra.fr/valor-pro_eng/Experimental-devices/EFELE). The EFELE site, established in 2012, assesses the agronomic value of composts and the environmental impacts of organic waste from livestock production. EFELE's soils are silty loam, classified as Epistagnic Haplic Luvisols according to the World Reference Base for Soil Resources (IUSS Working Group WRB, 2014), with a $\mathrm{pH}$ of 6.1 , a SOC content of $10.4 \mathrm{~g} \mathrm{~kg}^{-1}$ and particle-size distribution of $143 \mathrm{~g} \mathrm{~kg}^{-1}$ clay, $705 \mathrm{~g} \mathrm{~kg}^{-1}$ silt and $153 \mathrm{~g} \mathrm{~kg}^{-1}$ sand in the upper $30 \mathrm{~cm}$.

The experimental design consisted of two separate experiments, each with a different tillage system, CT and ST. For each trial, two fertilizer treatments (mineral and organic) were considered and randomly replicated three times (Figure 1). Therefore, the experimental system was composed of a total of 12 plots $(12.5 \mathrm{~m} \times 8.7 \mathrm{~m})$. The crop rotation was maize (Zea mays L.) and winter wheat (Triticum aetivum L.), with a nitrogen (N) catch crop of mustard (Sinapis hirta) between wheat and maize.

The four treatments studied were i) CT with mineral fertilizer (CTM), ii) CT with cattle manure (CTC), iii) ST with mineral fertilizer (STM) and iv) ST with cattle manure (STC). The CT was deep plowing to a depth of $22 \mathrm{~cm}$ with a moldboard and circular spike, while the ST was performed with a "Compil" equipped with circular rolling spades to a depth less than $10 \mathrm{~cm}$, without soil inversion. The mineral fertilizer was $\mathrm{N}$ applied as ammonium nitrate, with a mean dose of $92 \mathrm{~kg} \mathrm{~N} / \mathrm{ha}$ on maize and $118 \mathrm{~kg} \mathrm{~N} / \mathrm{ha}$ on wheat. This dose was calculated by considering crop needs, soil mineralization rate and an annual input of $50 \mathrm{~kg}$ of $\mathrm{P}_{2} \mathrm{O}_{5} / \mathrm{ha}$ and $60 \mathrm{~kg}$ of $\mathrm{K}_{2} \mathrm{O}$. The organic fertilizer (cattle manure) was applied before seeding the maize, using a spreader at a mean dose of 50 t/ha every two years beginning in 2012, and then landfilled using a "Compil" at a depth of 6 to $8 \mathrm{~cm}$. The dose was calculated based on an annual input of $100 \mathrm{~kg}$ of $\mathrm{P}_{2} \mathrm{O}_{5} / \mathrm{ha}$. The cattle manure provided more than $4 \mathrm{t} / \mathrm{ha}$ of organic matter per year. 
Two undisturbed soil blocks were collected at each plot: one each at 0-15 and 15-25 cm. Each

139 plot's soil was sampled twice: in February 2012, to define the initial state (T0) before starting 140 treatments, and in March 2017, after five years of treatments. The two sampling campaigns 141 were conducted before tillage. After each sampling campaign, the 24 soil blocks collected 142 were stored at $4^{\circ} \mathrm{C}$ until required for physical and spectral measurements.

\section{2. Assessment of the effects of agricultural practices on soil hydraulic properties}

2. 2. 1. Conventional approach based on soil physical and chemical properties

In the laboratory, each soil block was broken down at field capacity into aggregates approximately 3-4 $\mathrm{cm}$ wide and 5-6 $\mathrm{cm}$ long. Four aggregates were collected in quadruplicate for measurement. Once saturated with deionized water, all aggregates were placed on a suction table and then in a pressure cell to be gradually dried. Aggregates were brought successively to pressure heads of -1 and $-3.2 \mathrm{kPa}$ (corresponding to $\mathrm{pF} 1$ and 1.5 , respectively) on the suction table. Then they were brought to pressure heads of $-10,-20,-$ $31.6,-63,-100,-316,-1000$ and $-1585 \mathrm{kPa}$ (corresponding to $\mathrm{pF} 2,2.3,2.5,2.8,3,3.5,4$ and 4.2, respectively) using a pressure cell following the ISO 11274 standard (AFNOR, 1998). At each pressure head, the soil aggregates were weighed. Finally, the aggregates were oven-dried at $105^{\circ} \mathrm{C}$ for 48 hours, after which their dry mass was weighed to determine their gravimetric SWCs at the matric potentials. Dry BD was measured for whole aggregates by the kerosene-displacement method (Abrol and Palta, 1968), according to the X31-505 standard (AFNOR, 1992). For each soil aggregate, gravimetric SWC was converted to volumetric SWC, and total porosity was calculated assuming a particle density of $2.65 \mathrm{~g} \mathrm{~cm}^{-3}$. The SWCs of the four aggregates were averaged at different pressure heads, and their BDs were averaged

160 after they had been oven-dried. Their BDs were measured following kerosene displacement.

161 WHC for a specific thickness, z $(\mathrm{cm})$, of soil was calculated as follows: 
163

164

165

166

167

168

169

170

where FC is field capacity and PWP is permanent wilting point. Furthermore, when FC was not measured in the field, it was often estimated to be SWC around a pressure head of -33 $\mathrm{kPa}$, particularly for loamy soil (Kirkham, 2014). For our soil samples, we used the pressure head of $-31.6 \mathrm{kPa}$ (i.e. $\mathrm{pF}=2.5$ ) to assess $\mathrm{SWC}$ at $\mathrm{FC}$. WHC was calculated for a standard thickness $z$ of $10 \mathrm{~cm}$. Based on SWR characteristics, we estimated pore-size distribution according to capillary theory (Ahuja et al., 1998), assuming that pores were cylindrical capillaries described by Jurin's equation:

$$
S=\frac{2 \gamma \cos \beta}{\rho g r}
$$

where $\mathrm{S}(\mathrm{m})$ is soil water suction ( $\mathrm{S}=-h$, the pressure head), $r$ is the effective pore radius, $\gamma$ is the surface tension of water (at $20^{\circ} \mathrm{C}, \gamma=0.075 \mathrm{~N} \mathrm{~m}^{-1}$ ), $\beta$ is the contact angle of the water held in the pore (usually assumed to be zero, $\cos \beta=1), \rho$ is the density of water $\left(1000 \mathrm{~kg} \mathrm{~m}^{-3}\right.$ at $\left.20^{\circ} \mathrm{C}\right)$, and $g$ is gravitational acceleration $\left(9.81 \mathrm{~N} \mathrm{~kg}^{-1}\right)$.

The diameter $\mathrm{d}(\mu \mathrm{m})$ of the largest pores was calculated with a simplified equation:

$$
d=\frac{0.3}{S}
$$

It is well known that the impacts of soil tillage and fertilization are directly related to major physical and chemical soil properties such as SWC, WHC, BD, porosity and SOC content. Thus, in the conventional approach, the effects of tillage type and fertilizer type on these properties were examined to infer their effects on SWR properties. Additionally, impacts on soil structure and quality were estimated with the $S_{\text {Dexter }}$ index of soil physical quality (Dexter, 2004a):

$$
S_{\text {Dexter }}=-n\left(S W C_{0}-S W C_{r}\right)\left[1+\frac{1}{m}\right]^{-(1+m)}
$$


where $\mathrm{SWC}_{0}\left(\mathrm{~cm}^{3} \mathrm{~cm}^{-3}\right)$ is $\mathrm{SWC}$ at saturation, $\mathrm{SWC}_{\mathrm{r}}\left(\mathrm{cm}^{3} \mathrm{~cm}^{-3}\right)$ is the residual soil water content, $n>1$ is a measure of the pore-size distribution and $m$ is an empirical constant that can be related to $n$, such that $\mathrm{m}=1-1 / n$ (Van Genuchten, 1980). During the adjustment process, $\mathrm{SWC}_{\mathrm{r}}$ was found to be close to zero. It was therefore set to zero for all samples. In fact, $S_{\text {Dexter }}$ equals the slope of the SWR curve at its inflection point (Dexter, 2004a). Dexter (2004b) showed that $S_{\text {Dexter }}$ is linearly and positively correlated with friability and the ease of working the soil. Thus, as $S_{\text {Dexter }}$ increases, soil compaction decreases, which indicates good soil structure.

\section{2. 2. Alternative approach with spectral measurements}

Once the desired water pressure head was reached, and after the soil aggregates had been oven dried, reflectance spectra of soil samples were recorded with a full-range visible-NIR spectrometer (ASD Fieldspec® 3, Analytical Spectral Devices Inc., Boulder, CO, USA) from 350-2500 nm wavelengths, with a sampling interval of $1 \mathrm{~nm}$. The ASD spectrometer was used in a bare fiber optic configuration with a $25^{\circ}$ view angle. All spectra were recorded using a standard contact probe that embeds both an optical fiber and a halogen bulb light source with a color temperature of approximately $2901 \mathrm{~K}$. This reduces errors associated with stray light during measurement and atmospheric water content. Before spectral acquisition of each soil sample, the ASD spectrometer was optimized on a dark current followed by a white reference panel (Spectralon $®)$. Spectral measurements were taken in the laboratory in a dark room. At a given pressure head and for each soil aggregate, reflectance spectra were acquired in triplicate by slightly modifying the position of the contact probe. As a result, the single spectrum for a given soil aggregate at a given moisture was a mean of 30 scans, and the final spectrum used in the treatment was a mean of the three replicates. The total time for recording the spectra was standardized to $6 \mathrm{~s}$ per aggregate to avoid heating and drying the samples. Because of the low signal-to-noise ratio between 350 and $400 \mathrm{~nm}$, the spectral interval was narrowed to 400- 
$2500 \mathrm{~nm}$ (Mouazen et al., 2010), and the continuum removal technique (Clark and Roush, 1984) was applied to all spectral data. It was applied to facilitate the interpretation of the absorption features in a diffuse reflectance spectrum by normalizing spectra to a common convex hull.

In this alternative approach, the spectral reflectance values, and more precisely the SWSI, referred to in Soltani et al. (2019), were used as a unique predictor of the impacts of soil tillage and fertilization on SWR properties:

$S W S I_{i}=1-\frac{F W H M_{i}}{F W H M_{0}}$

where $i$ is a value of pressure head, $\mathrm{FWHM}_{i}$ is the full width at half maximum at the $i$ th pressure head and $\mathrm{FWHM}_{0}$ is the full width at half maximum at saturation.

Thus, using spectral data, we calculated the $\operatorname{SWSI}_{i}$ at the 11 available matric potentials: $0,-1$, $-3.2,-10,-20,-31.6,-63,-100,-316,-1000$ and $-1585 \mathrm{kPa}$. As in Soltani et al. (2019), the linear relation between SWSI and SWC was fitted for each soil sample to obtain the slope (i.e. the rate of water release from soil pores) and intercept (i.e. SWC at saturation). Thus, as the intercept increases, the maximum WHC of the soil increases, and as the absolute value of the slope (AvS) increases, SWR decreases. We also used the projection and position of soil samples on the slope vs. intercept plane to study the impact of tillage and fertilization on soil structure and SWR properties.

\section{3. Statistical analysis}

The experimental design consisted of two separate trials, each with a different tillage type (CT or ST), with two fertilizer treatments (mineral and organic) randomly replicated three times within each trial. Therefore, statistical analyses were carried out separately for the two trials. All statistical analyses were performed using the R statistical programming environment (v. 
3.5.0). Descriptive statistics of basic soil properties and soil spectral data were calculated and tested for normality (at $P<0.05$ ) using the Shapiro-Wilk test statistic. Analysis of variance (ANOVA) was used for both tillage systems to determine whether the effects of fertilizer type and soil depth and their interactions on soil physical and chemical properties and spectral data were significant. Prior to ANOVAs, the data were tested for homoscedasticity using Bartlett's test. When effects were significant at $P<0.05$, means were compared with Fisher's least significant difference (LSD) test. Pearson's correlation analyses were also performed to explore correlations between soil properties (WHC, BD, sand:clay ratio and $\mathrm{S}_{\text {Dexter }}$ ) and spectral parameter data (intercept and slope).

\section{Results}

\section{1. Soil organic carbon content and bulk density}

ANOVA showed that for ST soil fertilization, depth and their interaction had a significant effect at $\mathrm{P}<0.05$ on SOC content (Table 1). In contrast, for CT, the significant effects at $\mathrm{P}<0.05$ were only observed for depth on SOC and for soil fertilization on BD.

Pairwise comparison of mean BD and SOC content between soil depths at T0 and under each CT treatment (CTM and CTC) showed no significant difference except for T0, where SOC content was significantly higher at 0-15 cm (Table 2). Moreover, the mean BD and SOC did not differ significantly between T0, CTM and CTC, regardless of depth. In the case of the ST treatment, the comparison of mean BD did not show any significant difference between soil depths for a given treatment or between T0, STM and STC at each depth. In contrast, at 0-15 $\mathrm{cm}$ cattle manure fertilization had significantly higher SOC than at T0 or with mineral fertilization. Cattle manure's positive effect on SOC content was much more noticeable at 0$15 \mathrm{~cm}$, for which cattle manure fertilization had a SOC content $20 \%$ higher than at T0 and $10 \%$ higher than for mineral fertilization. At $15-25 \mathrm{~cm}$, the mean SOC of STM and STC was 
significantly lower than at T0. The comparison of mean SOC between soil depths showed a significant difference for STM and STC, but not for T0 (Table 2). Thus, under cattle manure (STC) and mineral fertilizer (STM), SOC content at $15-25 \mathrm{~cm}$ was $20 \%$ lower than at $0-15$ $\mathrm{cm}$.

Although five years of CT had no significant effect on SOC content, regardless of fertilizer treatment or depth, CTC had a slightly higher SOC content than at T0 or under CTM (Table 2). On the other hand, ST combined with mineral or organic input showed a significant increase in SOC content at 0-15 cm compared to T0, unlike in the untilled layer at $15-25 \mathrm{~cm}$, where it significantly decreased. Furthermore, five years of both CT and ST did not show any significant difference when comparing BD to T0, regardless of soil depth or fertilizer input (Table 2). However, according to the ANOVA (Table 1), fertilizer inputs had a significant effect under CT, and BDs were slightly higher (Table 1) under tilled layers with mineral or organic input than at T0.

\section{2. Soil water retention characteristics}

After five years of CT and ST treatments in combination with mineral and organic fertilizer inputs, the mean SWC, at pressure heads of $-3.2 \mathrm{kPa}$ and $-31.6 \mathrm{kPa}$, did not differ significantly from $\mathrm{T} 0$ at $0-15 \mathrm{~cm}$ (Table 3 ). In contrast, at a pressure head of $-1585 \mathrm{kPa}$, the mean SWC showed a significant difference between T0 and CTM, and between STM and STC. SWC under CTM was $7 \%$ greater than at T0, and $10 \%$ greater under STC than STM. For soil layers at $15-25 \mathrm{~cm}$, the only significant difference was observed between SWR under CTC and both T0 and CTM, at pressure heads of $-3.2 \mathrm{kPa}$ and $-31.6 \mathrm{kPa}$. SWR under CTC was $9 \%$ and $6 \%$ greater at $\mathrm{T} 0$ and under CTM, respectively. In the case of ST treatments, SWC differed significantly only between STM and STC at a pressure head of $-1585 \mathrm{kPa}$, and it was $11 \%$ lower under mineral than under cattle manure fertilization. WHC showed a 
significant effect of tillage and fertilizer input combinations only at $15-25 \mathrm{~cm}$. WHCs were highest under CT, but differed significantly only between CTC and T0, where WHC under CTC was $20 \%$ higher than at T0. Among the T0, STM and STC untilled layers, a significant difference was obtained between STM and STC, and WHC with mineral input was 10\% higher than with organic input.

Figure 2 shows the difference in SWC between the treatments and T0 as a function of pressure head, at $0-15 \mathrm{~cm}$ and $15-25 \mathrm{~cm}$. To a certain extent, the observed variations among treatments reflect differences in poral distribution between each treatment and T0. One can see that CT and ST combined with the fertilizer inputs did not behave similarly. Indeed, the difference in SWC for CT under cattle manure was positive over the entire pressure head range at both soil depths, and it was greater than or equal to the difference under mineral fertilization for pressure heads higher than $-1585 \mathrm{kPa}$. Overall, SWC under CT was higher than at $\mathrm{T} 0$, and the increase was more pronounced with cattle manure than with mineral input. The difference in SWC between CTM and T0 was positive except at some pressure heads in the interval $[-1000 \mathrm{kPa},-10 \mathrm{kPa}]$, where it was slightly negative. At the permanent wilting point $(-1585 \mathrm{kPa})$, the difference in SWC under CTM was higher than under CTC. Overall, the difference in SWC under STC and STM relative to T0, as a function of pressure head, had similar variations at both depths (Figure 2). Moreover, this difference was negative mainly in the pressure head interval $[-316 \mathrm{kPa},-10 \mathrm{kPa}]$, regardless of depth and fertilizer type. Unlike under CT, the effect of cattle manure under ST did not lead to increased SWC compared to T0 and even to STM. Thus, the difference in SWC with STC was lower than or equal to that with STM, everywhere except at the permanent wilting point (Figure 2). 
For both experimental trials (CT and ST), fertilization and depth greatly modified the poresize distribution (Figure 3). Macropore (diameter $>100 \mu \mathrm{m}$ ) volume was significantly larger under ST and CT than at T0 at both depths in the two trials. Mesopore $(30-100 \mu \mathrm{m})$ volume did not differ significantly among treatments in both trials except under STM, which had significantly larger mesopore volume than at T0 or under STC, regardless of depth. Small pores $(0.2-30 \mu \mathrm{m}$, “storage micropores") occupied the majority (ca. 50\%) of pore volume, and their volume did not differ significantly among treatments in both trials. Only CTC showed a significant increase in storage micropore volumes compared to T0 and CTM at $15-25 \mathrm{~cm}$. In the CT trial, the volume of very small pores $(<0.2 \mu \mathrm{m}$, "residual micropores") was significantly larger under CTM than at T0 or under CTC at $0-15 \mathrm{~cm}$, while at $15-25 \mathrm{~cm}$ there was no significant difference between treatments. Under ST, the volume of residual micropores was significantly smaller under STM than at T0 or under STC, regardless of 315 depth.

\section{4. Soil structure and soil quality}

317 Soil fertilization showed a significant $(\mathrm{P}<0.05)$ difference in the $\mathrm{S}_{\text {Dexter }}$ soil physical quality

318 index, compared to T0 in the CT experimental trial or in the ST trial. In the CT experimental trial, CTC and CTM had significantly smaller values of $S_{\text {Dexter }}$ (i.e. poor soil structure) than T0 at 0-15 cm, while no difference was observed at 15-25 cm (Figure 4). At both depths, STM had significantly lower $S_{\text {Dexter }}$ than T0, but the STC treatment had a significant effect only at $15-25 \mathrm{~cm}$ with an $\mathrm{S}_{\text {Dexter }}$ index lower than that at T0. In addition, $\mathrm{S}_{\text {Dexter }}$ values under STC varied widely at $0-15 \mathrm{~cm}$ (Figure 4). 
When we examined the relation between SWC and SWSI for all soil samples, measured SWC showed a highly significant $\left(P<<10^{-8}\right)$ linear relation with the SWSI $\left(R^{2}>0.98\right.$, Table 4$)$, decreasing as the SWSI increased (Figure 5), regardless of depth or fertilizer input. These results agree with Soltani et al. (2019), who found a decreasing linear relation between SWC and SWSI. The slopes of the regression lines ranged from -1.27 (CTM at $0-15 \mathrm{~cm}$ and CTC at $15-25 \mathrm{~cm}$ ) to -1.16 (STC at 0-15 cm). In the subsequent analysis, we examined the absolute value of the slope (AvS).

The slope and intercept of the linear relation between SWC and SWSI were mainly influenced by soil tillage and fertilization (Figure 5, Table 4). At 0-15 cm, STM had the largest intercept $\left(0.509 \mathrm{~cm}^{3} \mathrm{~cm}^{-3}\right)$, while T0 had the smallest $\left(0.476 \mathrm{~cm}^{3} \mathrm{~cm}^{-3}\right)$ (Table 4). At the same depth, CTM had the largest AvS (1.27), while STC had the smallest (1.16). At 15-25 cm, CTC had the largest intercept and AvS $\left(0.528 \mathrm{~cm}^{3} \mathrm{~cm}^{-3}\right.$ and 1.27 , respectively), while T0 had the smallest intercept $\left(0.491 \mathrm{~cm}^{3} \mathrm{~cm}^{-3}\right)$ and STC the smallest AvS (1.20). ANOVA of the intercept and AvS (Table 5) indicated that under the CT treatment, depth and fertilization had a significant effect only on the intercept at $P<0.05$, and no interaction was found between these two factors (depth and fertilization). In the case of the ST treatment, these factors had no significant effect on the intercept or on the AvS.

When we graphed the mean AvS vs. the mean intercept at $\mathrm{T} 0$ and under the four treatments (Figure 6), their distribution on the plane was related to soil tillage, fertilization and depth. Therefore, the relative position of a given soil treatment on this plane allows to compare its two properties, SWR and maximum WHC, with respect to those of the other treatments. Indeed, increasing the intercept leads to an increase in maximum WHC, while increasing the AvS leads to a decrease in SWR. The mean intercept and the mean AvS ranged from 0.476- 
ranged from $0.490-0.509 \mathrm{~cm}^{3} \mathrm{~cm}^{-3}$ and 1.16-1.23, respectively (Figure 6b). In addition, CTM at $0-15 \mathrm{~cm}$ and CTC at $15-25 \mathrm{~cm}$ had a larger AvS than T0 and ST, regardless of depth and fertilization.

At $0-15 \mathrm{~cm}$, moving from T0 to CTC mainly increased the mean intercept, while moving to CTM increased both the mean AvS and the mean intercept. Consequently, CTC had higher maximum WHC than that at T0, and CTM had higher maximum WHC and lower SWR compared to T0. Moving from T0 to STC or STM, the mean AvS decreased and thus SWR increased. However, STM had a higher intercept, and thus higher maximum WHC, than at T0. At $15-25 \mathrm{~cm}$, both the mean intercept and the mean AvS linearly increased when moving from T0 to CTM and then to CTC. On the other hand, STM had a higher mean intercept and mean AvS than that STC or at T0. Consequently, STM had a higher maximum WHC than at T0 at both depths.

\section{6. Correlation between soil physical properties and the AvS and intercept}

Pearson correlations between the AvS, intercept and soil physical and chemical properties (BD, WHC, SOC content and $\mathrm{S}_{\text {Dexter}}$ ) (Table 6) generally agreed with the previous results. The AvS was positively and significantly correlated with WHC $(r=0.62)$ and $S_{\text {Dexter }}(r=0.39)$, but not with BD or SOC content. The intercept was also positively and significantly correlated with WHC ( $\mathrm{r}=0.64)$ and $\mathrm{S}_{\text {Dexter }}(\mathrm{r}=0.34)$ and negatively (but not significantly) correlated with BD $(r=-0.18)$. Besides the correlation with the intercept and the AvS, $S_{\text {Dexter }}$ was also positively and significantly correlated to SOC $(r=0.21)$ and WHC $(r=0.74)$, while it was negatively and significantly correlated to BD $(-0.25)$. 


\section{Discussion}

\section{1. Impacts on soil organic carbon content}

The effects of soil tillage and fertilization on soil properties vary, and these variations depend on the system chosen. Many studies have compared the influence of CT and ST on soil physical, chemical and biological properties, often reporting contradictory results (Alvarez and Steinbach, 2009; Balesdent et al., 2000; Kabiri et al., 2015). The effects of tillage and fertilization on SOC content dynamics have long been studied because of their impacts on soil quality and functioning. As expected, organic fertilization immediately increases SOC content, generally in proportion to the amount of carbon applied (Larney and Angers, 2012). Our results showed significantly higher SOC content after five years of cattle manure fertilization than with mineral fertilization. Besides fertilization, SOC content was higher under ST than under CT. In this case, the positive effect of ST on SOC content was observed only at 0-15 cm, and CT had higher SOC contents at 15-25 cm than ST. In ST soils, crop residues and cattle manure enter and decompose in the topsoil. Thus, SOC content at $0-15 \mathrm{~cm}$ is generally higher under ST than under CT. The fresh organic matter that is lost during tillage and decomposes at depth can also explain the high SOC content under CT at 15-25 cm. Many studies tend to show considerably higher rates of carbon mineralization in the topsoil under ST or NT than under CT (Bescansa et al., 2006; Green et al., 2007). Our results suggest that five years of CT and cattle manure input increase SOC contents at $15-25 \mathrm{~cm}$.

\section{2. Impacts on bulk density}

Reviews of how tillage systems influence BD have yielded contradictory results. Some studies found that BD increased under NT compared to CT or ST (Alvarez and Steinbach, 2009; Bescansa et al., 2006; Osunbitan et al., 2005; Salem et al., 2015). Conversely, other reviews found that tillage systems had inconsistent effects on BD and total porosity (Kabiri et 
al., 2015; Strudley et al., 2008). In the present study, BD at 0-15 cm was higher under both ST and CT than at T0, which agrees with Strudley et al.'s (2008) results. BD was also slightly higher under CT than under ST, perhaps due to the longer persistence of loosened soil after chiseling than after moldboard plowing (Richard et al., 2004). The decrease in BD after ST agrees with the results obtained by Green et al. (2003), Moret and Arrúe (2007) and Strudley et al. (2008), among others. However, BD decreased only at $0-15 \mathrm{~cm}$, with no significant difference between ST and CT at $15-25 \mathrm{~cm}$, which is similar to Ferreras et al.'s (2000) findings. These results suggest that soils under CT were denser, most likely due to subsequent compaction in the topsoil. Plant root development may have increased soil porosity and consequently decreased BD under ST, since ST could favor more root development in the topsoil. Indeed, increased soil porosity due to increased SOC content at $15-25 \mathrm{~cm}$ in tilled soils may explain the lower BD in the study plots.

\section{3. Impacts on pore-size distribution}

Soil porosity is a key characteristic controlling SWR properties and plant root development, but it is also an important indicator of soil physical quality as influenced by agricultural practices. Tillage generally affects structural porosity, which results from the arrangement of soil aggregates, but not textural porosity, which is determined mainly by soil texture (Guérif et al., 2001). In the present study, soil porosity was lower under both CT and ST than at T0, but no significant difference was observed either at $0-15 \mathrm{~cm}$ or at $15-25 \mathrm{~cm}$. The decrease in soil porosity, especially structural, was due mainly to the decrease in soil volume during compaction, due in part to tractor use. Pore size distribution describes the complexity of structure in far more detail than porosity alone. For example, it is the fundamental basis for the concept of aggregates. Pore size can be classified into micropores, macropores, and in some definitions, mesopores. In the present study, agricultural practices showed differences in soil behavior due to water and air movement. The percentage of macropores was significantly 
higher under CT and ST treatments than at T0, with no significant difference in the percentage between organic and mineral fertilizers. Macropores play a major role in water movement and also serve as channels for root development and solute movement (Jarvis, 2007). Differences in macropore distribution between tilled soil (CT and ST) and T0 were most likely the result of less soil disturbance at T0. CT generally disrupts macroaggregates mechanically (Kabiri et al., 2015). Our findings agree with the results of Ferreras et al. (2000) and Bescansa et al. (2006). Other studies have also reported fewer macropores under CT than under conservation tillage (Osunbitan et al., 2005). Mesopore distribution did not differ significantly among treatments in both CT and ST trials. Only STM had a greater mesopore volume than STC and T0. The pore-size distribution also indicated no significant difference in the percentage of storage micropores among CT and ST treatments compared to T0. Only CTC had greater storage micropore volume at $15-25 \mathrm{~cm}$. Overall, tillage (CT and ST) in combination with fertilizer input appeared to appreciably change the volume of i) macro and mesopores at both depths, ii) storage micropores at $15-25 \mathrm{~cm}$ and iii) residual micropores at 0$15 \mathrm{~cm}$. The results of pore-size distribution agree with the behavior of BD and tillage-induced pores. Pore-size distribution is also modified by fertilization. The complex chemical and physical characteristics of fertilizers have variable effects on aggregation. Fertilizer applications generally increase soil aggregation and can increase both macroporosity and microporosity. This probably explains the increase in micropore volume at $15-25 \mathrm{~cm}$ under CTC.

\section{4. Impacts on soil water retention properties}

The relation between pore-size distribution and SWR properties among soil tillage systems and fertilization is complex. Water is held in the spaces (pores) between soil particles and within films surrounding these particles. SOC content and particle-size distribution affect a soil's ability to retain moisture and its WHC. The sum of the adsorbed and retained SWC is 
equal to the saturated SWC (Liu et al., 2013). Many factors can influence WHC, and the response to tillage may be uncertain (Strudley et al., 2008). Azooz and Arshad (2001) measured SWR at six matric suctions from 5-160 kPa and found that the rate of soil drying at 0-30 cm was significantly higher under CT than NT, while the rate of wetting was significantly higher under NT. In the present study, SWR characteristics, particularly WHC, were greater under CT than at T0. The differences in SWR observed between treatments resulted from a change in the pore-size distribution for compaction in a range of sizes corresponding to pores that contribute to SWR. Our results showed that tillage and fertilization affect SWR properties for pressure heads ranging from -1 to $-1585 \mathrm{kPa}$. The increase in retained SWC from -1 to $-31.6 \mathrm{kPa}$ probably corresponds to an increase in macroand mesopore volume. In the same way, the increase in retained SWC from -31.6 to -1582 $\mathrm{kPa}$ would correspond to the increase in storage micropore volume. The presence of small pores could have favored higher SWC, and under CT, cattle manure fertilization helped maintain higher $\mathrm{SWC}$ at $15-25 \mathrm{~cm}$.

\section{5. Impacts on soil structure quality}

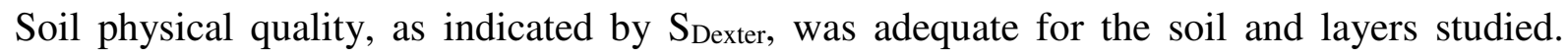
Regardless of the treatment, mean $S_{\text {Dexter }}$ was above the critical value (0.035) proposed by Dexter (2004a), indicating good soil structural and physical quality. Even after the repeated traffic over a five year period in both the ST and CT experimental trials, the soil maintained good structure. In addition, $S_{\text {Dexter }}$ tended to increase in organic fertilizer treatments, but not with mineral fertilization. Overall, compared to T0, physical soil quality in both CT and ST trials decreased, except for an improving trend at $15-25 \mathrm{~cm}$ with cattle manure input under CT. It is likely that spreading cattle manure increased SOC content and improved soil structure. SOC content is an important indicator of soil quality because of its significant effects on soil physical, chemical and biological properties. SOC is closely related to soil 
aggregate formation and stabilization (Balesdent et al., 2000). It is also strongly affected by agricultural management practices such as tillage (Six et al., 2002). In general, increasing SOC content can generally improve aggregate stability, suggesting that organic fertilization promotes greater structural stability and subsequently an improvement in soil structural quality.

According to Dexter (2004a), S Sexter generally decreases with increasing BD. This agrees with

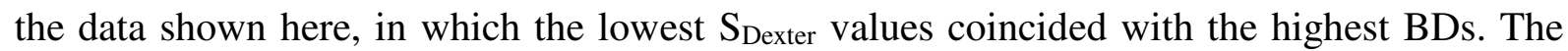
relation between $S_{\text {Dexter }}$ and BD, however, depends on soil texture (Dexter, 2004a). Recently, Naderi-Boldaji and Keller (2016) found a positive correlation between soil compaction and $\operatorname{Ln}\left(1 / \mathrm{S}_{\text {Dexter }}\right)$ that is less sensitive to soil texture. $\mathrm{S}_{\text {Dexter }}$ was generally lower under CT and ST than at the initial state. The compaction of soil due to tractor use in CT and ST could explain the decrease in $S_{\text {Dexter }}$ and thus soil physical quality. $S_{\text {Dexter }}$ is derived from the SWR curve. Therefore, it is closely related to pore-size distribution, which agrees with the variations in pore-size distribution observed among the treatments.

\section{6. Utility of the SWSI for evaluating soil tillage impacts on SWR properties}

In addition to the effects observed on SWR properties and soil quality, we considered the effect of tillage and fertilization on soil NIR reflectance. We were particularly interested in the SWSI NIR spectral index developed by Soltani et al. (2019) and the parameters of the SWC-SWSI relation. SWSI showed a significant linear relation with measured SWC, with an $R^{2}>0.99$ for all soil samples, which agrees with Soltani et al.'s (2019) results. They obtained a similar linear relation between SWC and SWSI from several soil samples taken from the organo-mineral A horizon $(0-30 \mathrm{~cm})$ in Brittany. SWC decreases linearly as SWSI increases. As suggested by Soltani et al. (2019), the AvS indicates how much SWC changes during drying per unit of change in SWSI. The smaller the AvS, the smaller the change in SWC and 
in the associated amount of water released. The AvS is thus related to SWR. The intercept was obtained when SWSI equaled zero, which was at saturation for FWHM and corresponded to the theoretical value of SWC at saturation. According to Soltani et al. (2019), the intercept and the AvS appeared relevant for studying the effects of texture and SOC content on SWR properties. Therefore, the distribution and relative positions of soil samples on the plane of the intercept vs. AvS graph result from the combination of their respective porosity and SWR capacity. In the present study, only soil depth and fertilizer under CT had a significant effect on the intercept and therefore on SWR properties, and on WHC in particular. Overall, compared to T0, CT treatments had the largest mean intercept and mean AvS, which indicated an overall positive effect of tillage on SWR properties and soil porosity. Moreover, the correlation matrix showed significant positive correlations between WHC, $\mathrm{S}_{\text {Dexter }}$ and the two parameters (intercept, AvS). This thus explains the overall consistency observed between soil sample distribution on the plane and the effects of agricultural practices on physical and chemical parameters (e.g. porosity, WHC, S Sexter, BD, SOC content). For example, cattle manure fertilization and the increase in SOC content had a pronounced effect on the intercept of agricultural practices on soil physical properties.

The soil under CTC at $15-25 \mathrm{~cm}$ had a larger intercept and AvS than at T0 or under STM and

512 STC, at both depths. Thus, this soil was assumed to have better structure and physical quality 513 than the other soil samples. This was reflected in its poral distribution that allowed i) water to be easily available, since it had higher SWC variation for a SWSI unit variation and, ii) higher $\mathrm{S}_{\text {Dexter }}$ and WHC, likely in combination with the increase in SOC content due to cattle manure input. At 0-15 cm, according to Dexter's criterion, both T0 and CTM had good physical 517 quality. Soil quality was even better for T0, which had a higher $S_{\text {Dexter. }}$ However, the relative 
position of CTM on the plane with respect to T0 pointed to the opposite conclusion. Indeed,

519 CTM had a higher AvS and intercept. The same observation can be made with T0 and STM at $15-25 \mathrm{~cm}$ when comparing their $\mathrm{S}_{\text {Dexter }}$ and their relative position on the plane. Soil physical quality is multifactorial and therefore not straightforward to evaluate. Thus, a single index, such as $S_{\text {Dexter, }}$ may be insufficient to characterize this quality. The plane has an advantage since it offers a bidimensional approach combining SWR properties and poral distribution, through the use of intercept and Avs coordinates, to evaluate the physical quality. However, for this plane to be even more relevant, thresholds must be defined for both the AvS and the intercept, thus making it possible to characterize soil physical quality.

\section{Conclusion}

In the present study, we used two approaches to study the effects of five years of tillage and fertilization on SWR properties and soil structural quality. The first approach consisted of using soil physical, chemical and SWR properties to assess the effects of agricultural practices on SWR properties and then on soil structural quality. The second approach used spectral soil information to study the effects of tillage and fertilization on SWR properties and structural quality. This second approach is derived from results obtained by Soltani et al. (2019), based on the water characteristic absorption band near $1920 \mathrm{~nm}$. We further compared the results of the two approaches.

Five years of tillage combined with mineral and organic fertilization significantly impacted SWR properties. CT generally had a more positive effect on SWR properties than T0 and this effect was more pronounced with organic than with mineral fertilization and at $15-25 \mathrm{~cm}$.

539 SWC, WHC and porosity were greater under CTC than under either CTM or T0. SDexter under

540 CTC was also greater than under CTM and at T0, indicating a generally positive effect on physical soil quality, but the difference was not significant. However, ST appeared to have a 
more negative effect on SWR properties than at T0, and cattle manure fertilization did not lead to a significant increase in SWR properties compared to T0 or STM. Overall, fertilization had no significant effect on soil properties, which directly influence SWR. Nevertheless, cattle manure fertilization played an important role in improving the physical quality of tilled soils. To achieve these results, several soil properties were analyzed, but similar results have been achieved when analyzing only NIR spectral properties of soil. Our results suggest that the AvS and the intercept of the linear relation between SWSI and SWC were relevant for studying the effects of tillage type and fertilization type on SWR properties and soil structural quality. What is more, plotting the intercept vs. AvS offers a way to summarize and assess the impacts of agricultural practices on these properties. An increase in the intercept and AvS was generally associated with an improvement in soil quality.

Our findings suggest that spectral information, as a promising alternative approach, can be used to asses SWR properties and soil structural quality. Reflectance is a dynamic soil property that can change rapidly due to changes in soil composition, compaction, structural degradation and biological processes. Using spectral data, one can infer a variety of soil properties that may influence SWR properties and soil quality. Since five years is a mediumterm time horizon, some effects were not significantly discriminated. It thus appears that our alternative method would likely be even more relevant in long-term trials. Along with reflectance, the SWR curve (SWC vs. pressure head) is one of the key soil characteristics that convey a great deal of soil information. For example, $S_{\text {Dexter }}$ is theoretically derived from the inflection point of the SWR curve. Estimating hydraulic properties at multiple locations, even within an agricultural field, is time-consuming and costly. Nevertheless, in the present study, NIR spectroscopy showed promising results for studying SWR properties. Therefore, further research could focus on estimating SWSI to predict the SWR curve. 


\section{Acknowledgements}

568

569

570

571

572

573

574

575

576

577

578

579

580

581

582

583

584

585

586

587

588

589

590

The EFELE field experiment forms part of the SOERE-PRO (network of long-term experiments dedicated to the study of impacts of organic waste product recycling). It is certified by ALLENVI (Alliance Nationale de Recherche pour l'Environnement) and integrated as a service of the "Investment d'Avenir"' infrastructure AnaEE-France, overseen by the French National Research Agency (ANR-11-INBS-0001). The authors are grateful to T. Morvan for providing access to the EFELE site and to F. Gaillard for assistance with fieldwork. The authors also appreciate the help provided by Ms. P. Breger and Mr. R. Dubois during sample collection, measurements of soil retention properties and spectral acquisition in the laboratory. The first author is supported by a Ph.D. grant from the Tunisian Republic.

\section{References}

Abiven, S., Menasseri, S., Chenu, C., 2009. The effects of organic inputs over time on soil aggregate stability - A literature analysis. Soil Biology and Biochemistry 41, 1-12. 10.1016/j.soilbio.2008.09.015.

Abrol, I.P., Palta, J.P., 1968. Bulk density determination of soil clods using rubber solution as a coating material. Soil Science 106, 465-468. https://doi.org/10.1097/00010694-196812000-00010.

AFNOR, 1992. Norme X31-505. Qualité des sols-Méthodes physiques-Méthode de détermination du volume apparent et du contenu en eau des mottes. Association Française de Normalisation, ParisLa défense.

AFNOR, 1998. Norme NF ISO 11274. Qualité du sol-Détermination de la caractéristique de la rétention en eau-Méthodes de laboratoire. Association Française de Normalisation, Paris-La défense. Ahuja, L.R., Fiedler, F., Dunn, G.H., Benjamin, J.G., Garrison, A., 1998. Changes in soil water retention curves due to tillage and natural reconsolidation. Soil Science Society of America Journal 62, 1228-1233. https://doi.org/10.2136/sssaj1998.03615995006200050011x. 
Alvarez, R., Steinbach, H.S., 2009. A review of the effects of tillage systems on some soil physical

592 properties, water content, nitrate availability and crops yield in the Argentine Pampas. Soil and Tillage

593 Research 104, 1-15. https://doi.org/10.1016/j.still.2009.02.005.

594 Azooz, R.H., Arshad, M.A., 2001. Soil water drying and recharge rates as affected by tillage under 595 continuous barley and barley-canola cropping systems in northwestern Canada. Canadian Journal of 596 Soil Science 81, 45-52. https://doi.org/10.4141/cjss2013-015.

597 Babaeian, E., Homaee, M., Montzka, C., Vereecken, H., Norouzi, A.A., 2015a. Towards retrieving 598 soil hydraulic properties by hyperspectral remote sensing. Vadose Zone Journal 14. 599 https://doi.org/10.2136/vzj2014.07.0080.

600 Babaeian, E., Homaee, M., Vereecken, H., Montzka, C., Norouzi, A.A., van Genuchten, M.T., 2015 b. 601 A comparative study of multiple approaches for predicting the soil-water retention curve: 602 hyperspectral information vs. basic soil properties. Soil Science Society of America Journal 79, 1043603 1058. https://doi.org/10.2136/sssaj2014.09.0355.

604 Bai, Z., Caspari, T., Gonzalez, M.R., Batjes, N.H., Mäder, P., Bünemann, E.K., et al., 2018. Effects of 605 agricultural management practices on soil quality: A review of long-term experiments for Europe and 606 China. Agriculture, Ecosystems \& Environment 265, 1-7. 10.1016/j.agee.2018.05.028.

607 Balesdent, J., Chenu, C., Balabane, M., 2000. Relationship of soil organic matter dynamics to physical 608 protection and tillage. Soil and Tillage Research 53, 215-230. https://doi.org/10.1016/S0167$609 \quad 1987(99) 00107-5$.

610 Bescansa, P., Imaz, M.J., Virto, I., Enrique, A., Hoogmoed, W.B., 2006. Soil water retention as 611 affected by tillage and residue management in semiarid Spain. Soil and Tillage Research 87, 19-27. 612 https://doi.org/10.1016/j.still.2005.02.028.

613 Bottinelli, N., Angers, D.A., Hallaire, V., Michot, D., Le Guillou, C., Cluzeau, D., et al., 2017. Tillage 614 and fertilization practices affect soil aggregate stability in a humic cambisol of northwest France. Soil 615 and Tillage Research 170, 14-17. https://doi.org/10.1016/j.still.2017.02.008.

616 Cañasveras, J.C., Barrón, V., del Campillo, M.C., Torrent, J., Gómez, J.A., 2010. Estimation of 617 aggregate stability indices in Mediterranean soils by diffuse reflectance spectroscopy. Geoderma 158, 618 78-84. https://doi.org/10.1016/j.geoderma.2009.09.004. 
Clark, R.N., Roush, T.L., 1984. Reflectance spectroscopy: Quantitative analysis techniques for remote

620 sensing applications. Journal of Geophysical Research: Solid Earth 89, 6329-6340. 621 https://doi.org/10.1029/JB089iB07p06329.

622 Czyż, E.A., Dexter, A.R., 2008. Soil physical properties under winter wheat grown with different 623 tillage systems at selected locations. International Agrophysics 22, 191-200.

624 Dalal, R.C., Henderson, P.A., Glasby, J.M., 1991. Organic matter and microbial biomass in a vertisol 625 after 20 yr of zero-tillage. Soil Biology and Biochemistry 23, 435-441. https://doi.org/10.1016/0038$626 \quad 0717(91) 90006-6$.

627 Dexter, A.R., 2004a. Soil physical quality - Part I. Theory, effects of soil texture, density, and 628 organic matter, and effects on root growth. Geoderma 120, 201-214. 629 https://doi.org/10.1016/j.geodermaa.2003.09.005.

630 Dexter, A.R., 2004b. Soil physical quality: Part II. Friability, tillage, tilth and hard-setting. Geoderma 631 120, 215-225. https://doi.org/10.1016/j.geoderma.2003.09.005.

632 Ferreras, L.A., Costa, J.L., Gracia, F.O., Pecorari, C., 2000. Effect of no-tillage on some soil physical 633 properties of a structural degraded petrocalcic paleudoll of the southern "pampa" of Argentina. Soil 634 and Tillage Research 54, 31-39. https://doi.org/10.1016/S0167-1987(99)00102-6.

635 Gomez, C., Le Bissonnais, Y., Annabi, M., Bahri, H., Raclot, D., 2013. Laboratory Vis-NIR 636 spectroscopy as an alternative method for estimating the soil aggregate stability indexes of 637 Mediterranean soils. Geoderma 209-210, 86-97. https://doi.org/10.1016/j.geoderma.2013.06.002.

638 Green, T.R., Ahuja, L.R., Benjamin, J.G., 2003. Advances and challenges in predicting agricultural 639 management effects on soil hydraulic properties. Geoderma 116, 3-27. https://doi.org/10.1016/s0016640 7061(03)00091-0.

641 Green, V., Stott, D., Cruz, J., Curi, N., 2007. Tillage impacts on soil biological activity and 642 aggregation in a Brazilian Cerrado Oxisol. Soil and Tillage Research 92, 114-121. 643 https://doi.org/10.1016/j.still.2006.01.004.

644 Guérif, J., Richard, G., Durr, C., Machet, J.M., Recous, S., Roger-Estrade, J., 2001. A review of tillage 645 effects on crop residue management, seedbed conditions and seedling establishment. Soil and Tillage 646 Research 61, 13-32. https://doi.org/10.1016/S0167-1987(01)00187-8. 
IPBES, 2018. Intergovernmental Science-Policy Platform on Biodiversity and Ecosystem Services.

648 The assessment report of land degradation and restoration, p. 965. https://www.ipbes.net/assessment649 reports/ldr.

650 Janik, L.J., Forrester, S.T., Rawson, A., 2009. The prediction of soil chemical and physical properties 651 from mid-infrared spectroscopy and combined partial least-squares regression and neural networks 652 (PLS-NN) analysis. Chemometrics and Intelligent Laboratory Systems 97, 179-188. 653 https://doi.org/10.1016/j.chemolab.2009.04.005.

654 Jarvis, N.J., 2007. A review of non-equilibrium water flow and solute transport in soil macropores: 655 principles, controlling factors and consequences for water quality. Eur. J. Soil Sci. 58, 523-546. 656 https://doi.org/10.1111/j.1365-2389.2007.00915.x.

657 Jiao, Y., Whalen, J.K., Hendershot, W.H., 2006. No-tillage and manure applications increase 658 aggregation and improve nutrient retention in a sandy-loam soil. Geoderma 134, 24-33. $659 \quad 10.1016 /$ j.geoderma.2005.08.012.

660 Kabiri, V., Raiesi, F., Ghazavi, M.A., 2015. Six years of different tillage systems affected aggregate661 associated SOM in a semi-arid loam soil from Central Iran. Soil and Tillage Research 154, 114-125. 662 https://doi.org/10.1016/j.still.2015.06.019.

663 Kirkham, M.B., 2014. Chapitre10-Field Capacity, Wilting Point, Available Water, and the 664 Nonlimiting Water Range, In: Kirkham, M.B. (Ed.), Principles of Soil and Plant Water Relations 665 (Second Edition). Academic Press, Oxford, UK, pp. 153-170.

666 Larney, F.J., Angers, D.A., 2012. The role of organic amendments in soil reclamation: A review. 667 Canadian Journal of Soil Science 92, 19-38.

668 Lipiec, J., Kuś, J., Słowińska-Jurkiewicz, A., Nosalewicz, A., 2006. Soil porosity and water infiltration 669 as influenced by tillage methods. Soil and Tillage Research 89, 210-220. 670 https://doi.org/10.1016/j.still.2005.07.012.

671 Lipiec, J., Nosalewicz, A., 2004. The effects of soil compaction on plant root growth, function and 672 stomatal diffusive resistance, In: Lipiec, J., Nosalewicz, A., Józefaciuk, G. (Eds.), Plant growth in 673 relation to soil physical conditions. IA PAS Press, Lublin, Poland, pp. 86-94. 

practices on the soil water-holding capacity of a non-irrigated apple orchard in the Loess Plateau, China. Soil and Tillage Research 130, 7-12. https://doi.org/10.1016/j.still.2013.01.012. Mahmoodlu, M.G., Raoof, A., Sweijen, T., van Genuchten, M.T., 2016. Effects of sand compaction and mixing on pore structure and the unsaturated soil hydraulic properties. Vadose Zone Journal 15. https://doi.org/10.2136/vzj2015.10.0136.

680 Maillard, E., Angers, D.A., 2014. Animal manure application and soil organic carbon stocks: a meta681 analysis. Glob Chang Biol 20, 666-679. 10.1111/gcb.12438. Mikha, M.M., Rice, C.W., 2004. Tillage and manure effects on soil and aggregate-associated carbon and nitrogen. Soil Science Society of America Journal 68, 809-816. 10.2136/sssaj2004.8090. Module in Earth Systems and Environmental Sciences. https://doi.org/10.1016/b978-0-12-4095489.09163-6.

Moret, D., Arrúe, J.L., 2007. Characterizing soil water-conducting macro- and mesoporosity as influenced by tillage using tension infiltrometry. Soil Science Society of America Journal 71, 500506. https://doi.org/10.2136/sssaj2006.0128.

Mouazen, A.M., Kuang, B., De Baerdemaeker, J., Ramon, H., 2010. Comparison among principal component, partial least squares and back propagation neural network analyses for accuracy of 692 measurement of selected soil properties with visible and near infrared spectroscopy. Geoderma 158, 693 23-31. 10.1016/j.geoderma.2010.03.001.

694 Naderi-Boldaji, M., Keller, T., 2016. Degree of soil compactness is highly correlated with the soil 695 physical quality index S. Soil and Tillage Research 159, 41-46. 696 https://doi.org/10.1016/j.still.2016.01.010.

697 Nocita, M., Stevens, A., Noon, C., van Wesemael, B., 2013. Prediction of soil organic carbon for 698 different levels of soil moisture using Vis-NIR spectroscopy. Geoderma 199, 37-42. 699 https://doi.org/10.1016/j.geoderma.2012.07.020. 
Osunbitan, J.A., Oyedele, D.J., Adekalu, K.O., 2005. Tillage effects on bulk density, hydraulic

conductivity and strength of a loamy sand soil in southwestern Nigeria. Soil and Tillage Research 82, 57-64. https://doi.org/10.1016/j.still.2004.05.007.

Richard, G., Sillon, J.F., Cousin, I., Bruand, A., 2004. Travail du sol, structure et fonctionnement hydrique du sol en régime d'évaporation. Etude et gestion des sols, association française pour l'étude des sols 11, 59-68.

Roger-Estrade, J., Anger, C., Bertrand, M., Richard, G., 2010. Tillage and soil ecology: Partners for $\begin{array}{llllll}\text { sustainable } & \text { agriculture. } & \text { Soil and } & \text { Tillage }\end{array}$ https://doi.org/10.1016/j.still.2010.08.010.

Salem, H.M., Valero, C., Muñoz, M.Á., Rodríguez, M.G., Silva, L.L., 2015. Short-term effects of four tillage practices on soil physical properties, soil water potential, and maize yield. Geoderma 237-238, 60-70. https://doi.org/10.1016/j.geoderma.2014.08.014.

Santra, P., Sahoo, R.N., Das, B.S., Samal, R.N., Pattanaik, A.K., Gupta, V.K., 2009. Estimation of soil hydraulic properties using proximal spectral reflectance in visible, near-infrared, and shortwaveinfrared (VIS-NIR-SWIR) region. Geoderma 152, $338-349$. https://doi.org/10.1016/j.geoderma.2009.07.001.

Sarathjith, M.C., Das, B.S., Vasava, H.B., Mohanty, B., Sahadevan, A.S., Wani, S.P., et al., 2014. Diffuse reflectance spectroscopic approach for the characterization of soil aggregate size distribution. Soil Science Society of America Journal 78, 369. https://doi.org/10.2136/sssaj2013.08.0377.

Six, J., Feller, C., Denef, K., Ogle, S.M., de Moraes, J.C., Albrecht, A., 2002. Soil organic matter, biota and aggregation in temperate and tropical soils-effects of no-tillage. Agronomie 22, 755-775. https://doi.org/10.1051/agro:2002043.

Soltani, I., Fouad, Y., Michot, D., Bréger, P., Dubois, R., Cudennec, C., 2019. A near infrared index to assess effects of soil texture and organic carbon content on soil water content. Eur. J. Soil Sci. 70, 151161. 10.1111/ejss.12725.

Soriano-Disla, J.M., Janik, L.J., Viscarra Rossel, R.A., MacDonald, L.M., McLaughlin, M.J., 2014. The performance of visible, near-, and mid-infrared reflectance spectroscopy for prediction of soil 
727 physical, chemical, and biological properties. Applied Spectroscopy Reviews 49, 139-186.

728 https://doi.org/10.1080/05704928.2013.811081.

729 Strudley, M., Green, T., Ascoughii, J., 2008. Tillage effects on soil hydraulic properties in space and

730 time: State of the science. Soil and Tillage Research 99, 4-48.

731 https://doi.org/10.1016/j.still.2008.01.007.

732 Tauro, F., Selker, J., van de Giesen, N., Abrate, T., Uijlenhoet, R., Porfiri, M., et al., 2018.

733 Measurements and Observations in the XXI century (MOXXI): innovation and multi-disciplinarity to

734 sense the hydrological cycle. Hydrological Sciences Journal 63, 169-196.

735 https://doi.org/10.1080/02626667.2017.1420191.

736 Van Genuchten, M.T., 1980. A closed-form equation for predicting the hydraulic conductivity of

737 unsaturated soils. Soil Science Society of America Journal 44, 892-898.

738 https://doi.org/10.2136/sssaj1980.03615995004400050002x.

739 Viscarra Rossel, R.A., Behrens, T., 2010. Using data mining to model and interpret soil diffuse

740 reflectance spectra. Geoderma 158, 46-54. https://doi.org/10.1016/j.geoderma.2009.12.025. 
1 Figure 1. Location of the EFELE experimental site and the experimental plot design (plots

2 are marked by identification number)

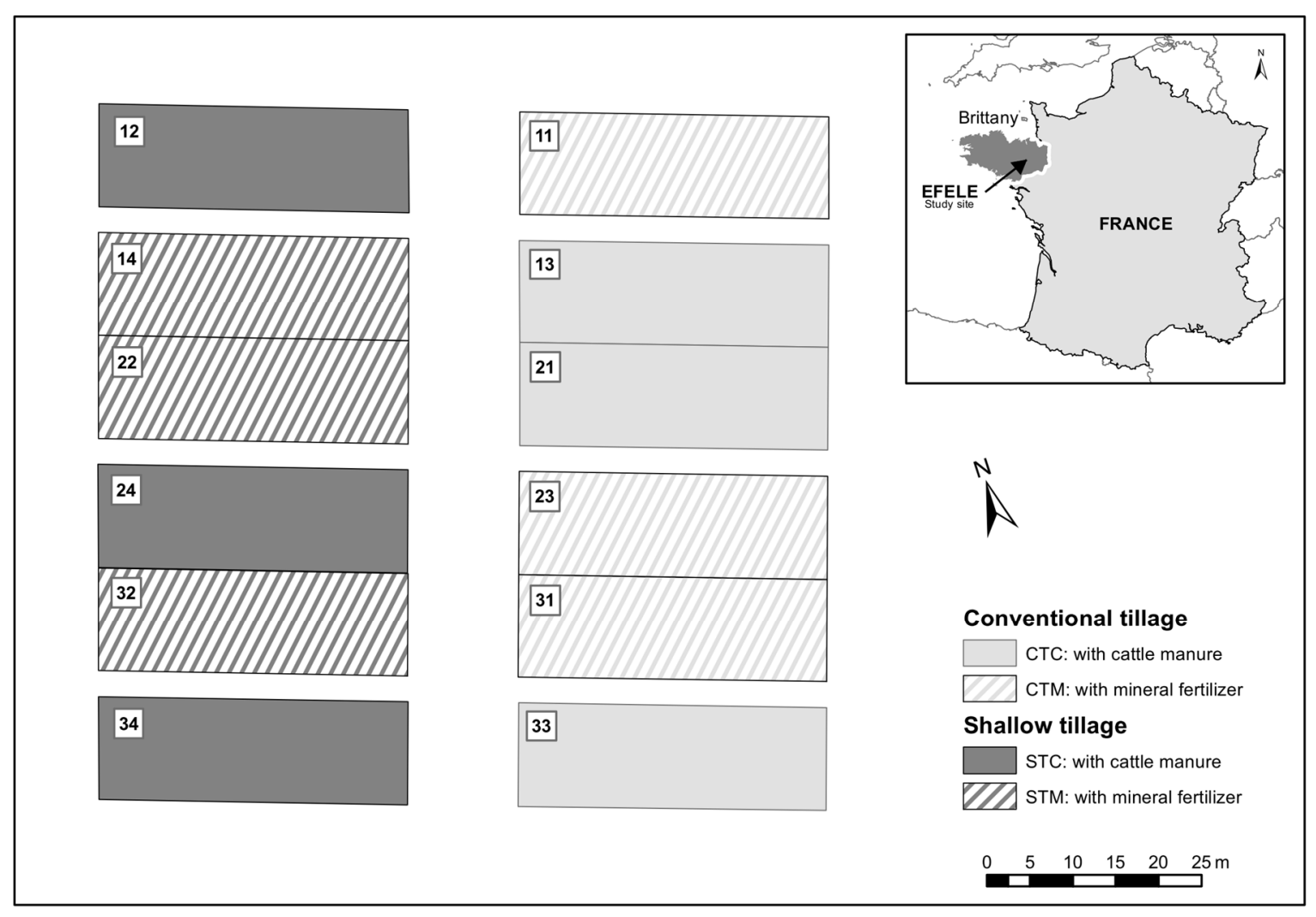

3

4

5

6

7

8 
9 Figure 2. Difference between mean soil water content under four treatments (CTC, CTM,

10 STC and STM) and at the initial state (T0) as a function of pressure head. Error bars indicate

111 standard error. STM is shallow tillage with mineral fertilizer; STC is shallow tillage with

12 cattle manure; CTM is conventional tillage with mineral fertilizer and CTC is conventional

13 tillage with cattle manure
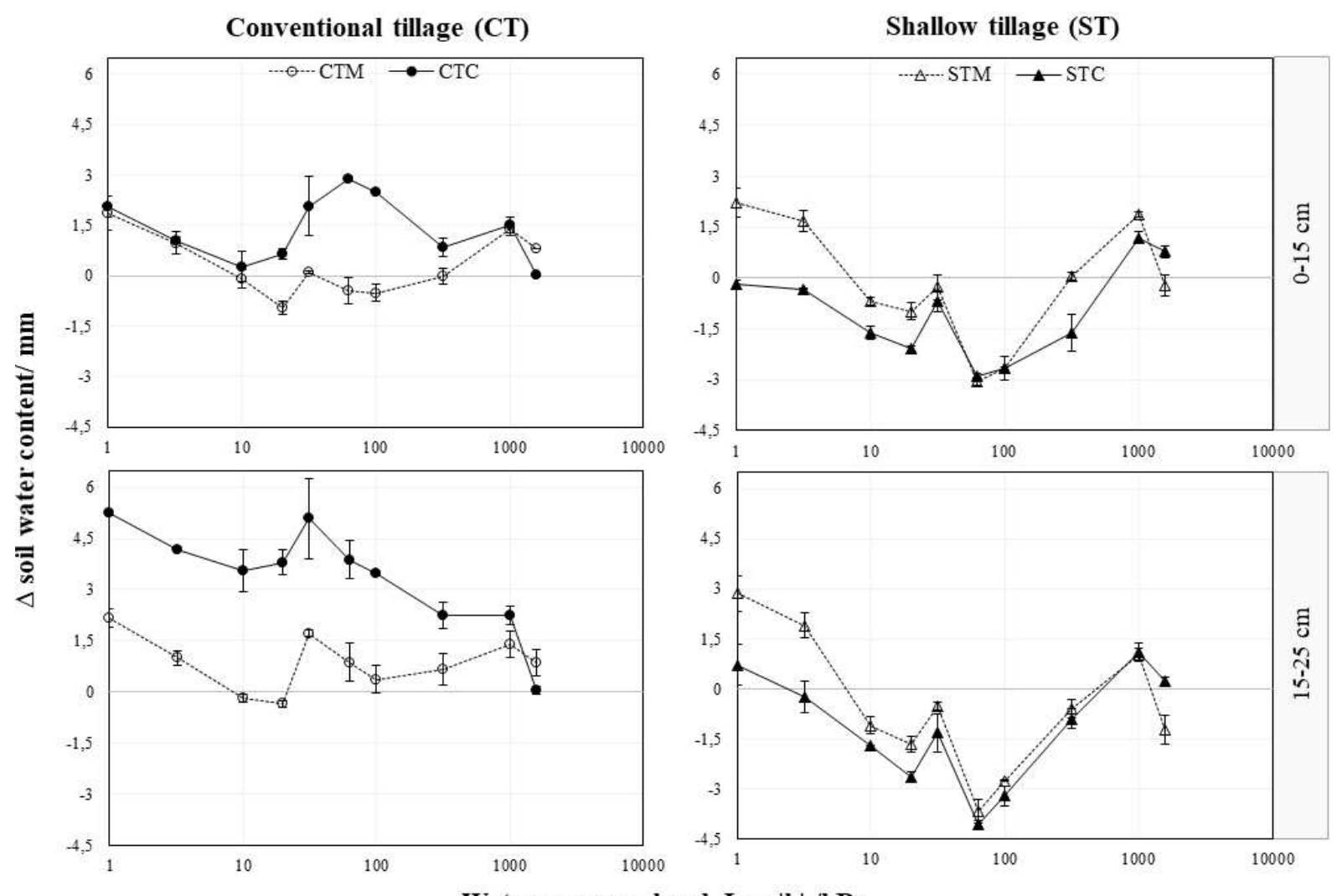

14

Water pressure head, $\log |\mathbf{h}| / \mathbf{k P a}$ 
Figure 3. Pore-size distribution of soil samples at two depths at the initial state (T0) and under four treatments: STM, shallow tillage with mineral fertilizer; STC, shallow tillage with cattle manure; CTM, conventional tillage with mineral fertilizer; CTC, conventional tillage

23 with cattle manure. Error bars indicate 1 standard error. Values with different letters are 24 significantly different $(P<0.05)$ according to ANOVA.
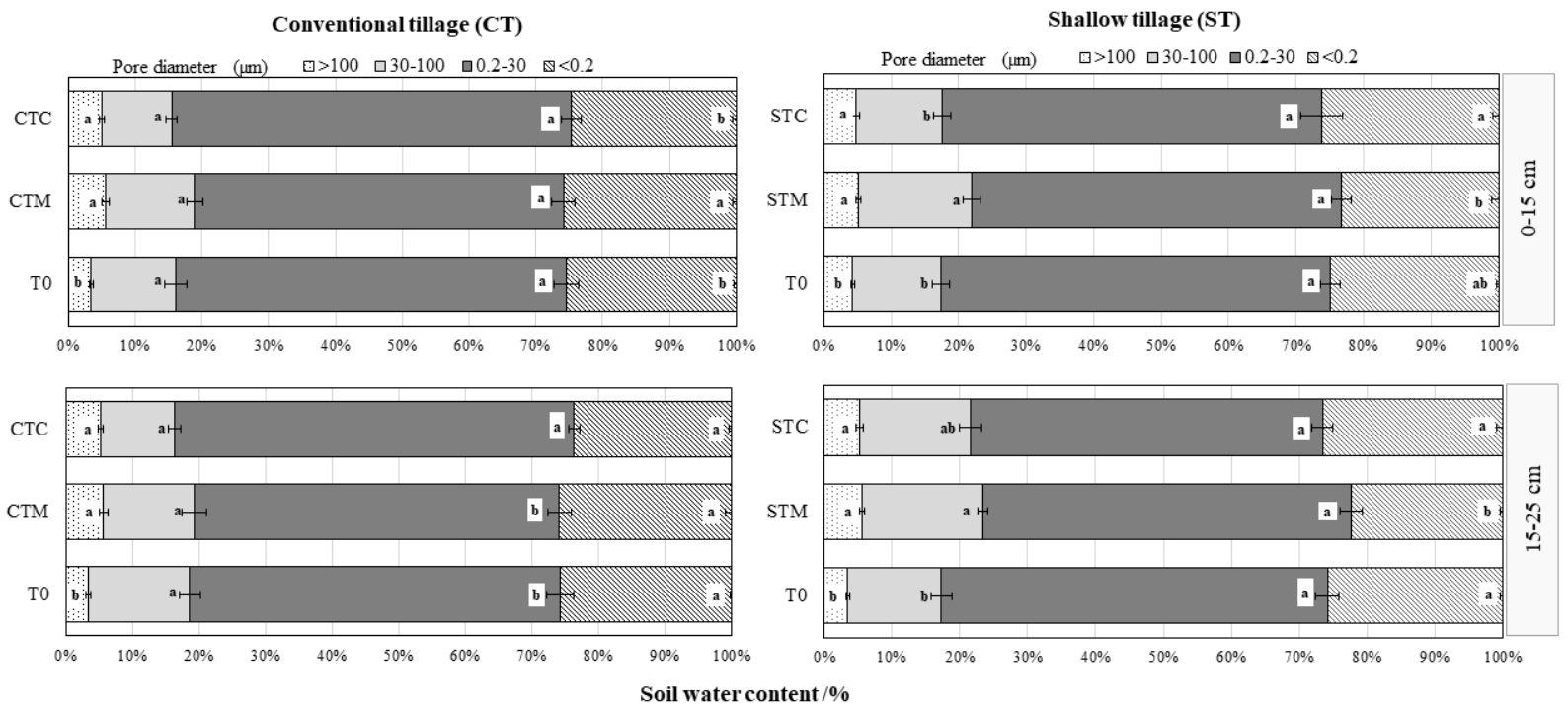
Figure 4. The $\mathrm{S}_{\text {Dexter }}$ index of soil physical quality at two depths $(0-15$ and $15-25 \mathrm{~cm})$ before (T0) and after five years of treatment (STM, STC, CTM and CTC). Whiskers represent 1.5 times the interquartile range. Values with different letters are significantly different $(\mathrm{P}<0.05)$ according to ANOVA. STM is shallow tillage with mineral fertilizer; STC is shallow tillage with cattle manure; CTM is conventional tillage with mineral fertilizer and CTC is conventional tillage with cattle manure

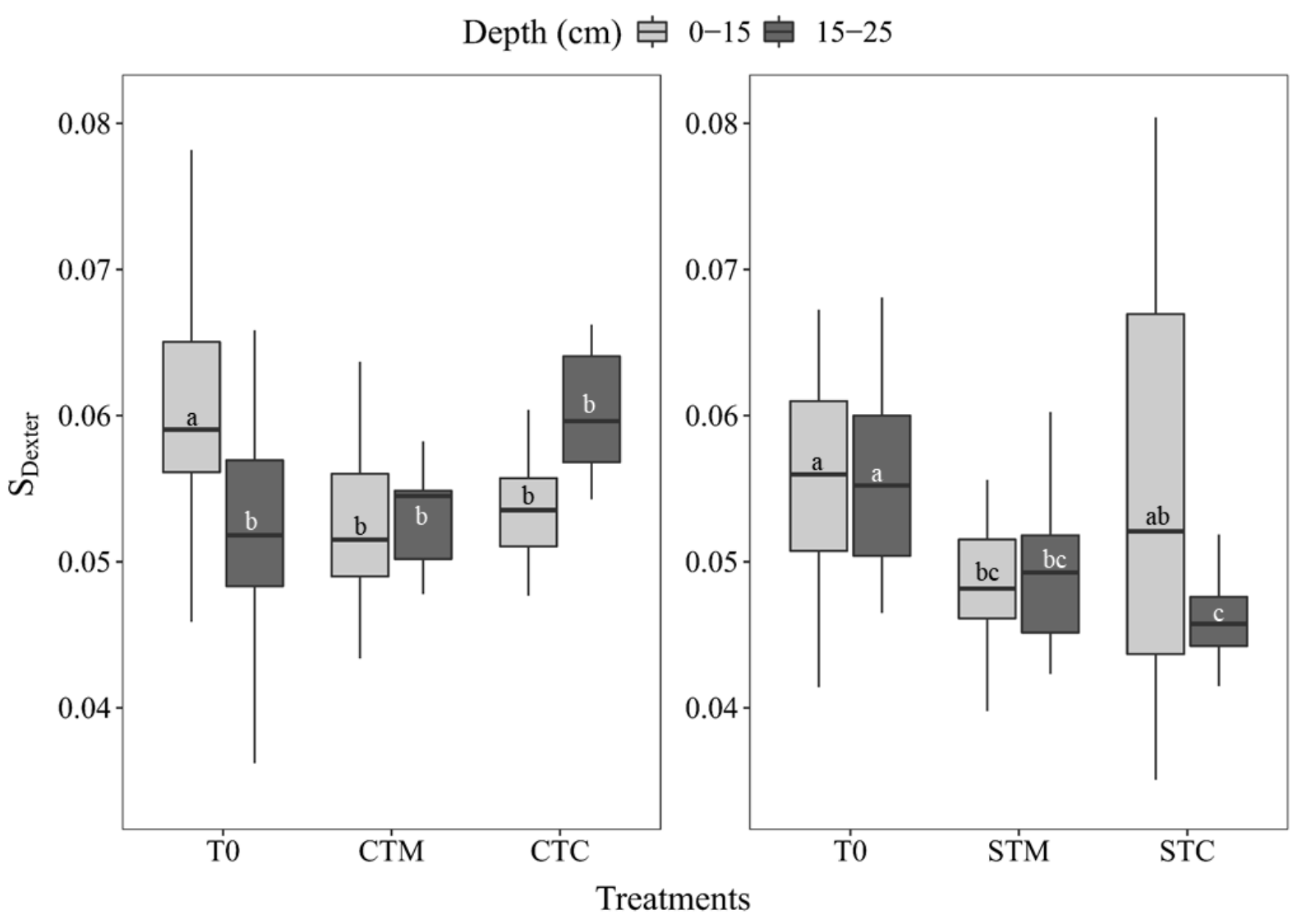


Figure 5. Soil water content at two depths $(0-15$ and $15-25 \mathrm{~cm})$ as a function of the soil water spectral index (SWSI) for four treatments: a) mineral fertilization with shallow tillage (STM) and conventional tillage (CTM); b) cattle manure fertilization with shallow tillage (STC) and conventional tillage (CTC). Treatments are compared to samples from T0, the initial state

41 before tillage and fertilization began in 2012 .

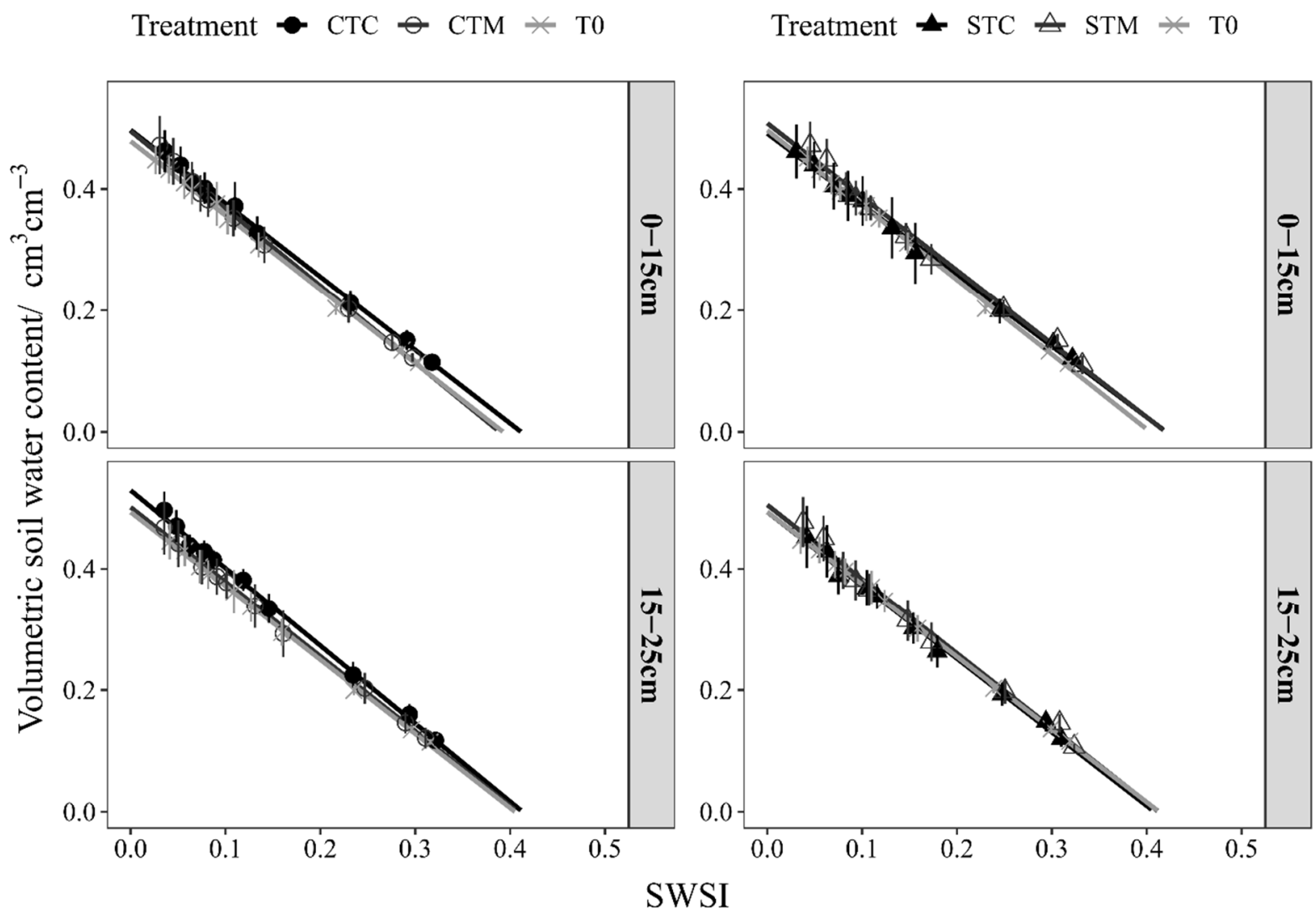

42 
44 Figure 6. Mean intercept vs. mean absolute value of the slope (AvS) of the relationship 45 between the soil water spectral index and soil water content at the initial state (T0) and under 46 four treatments at two depths $(0-15$ and $15-25 \mathrm{~cm})$. STM is shallow tillage with mineral 47 fertilizer; STC is shallow tillage with cattle manure; CTM is conventional tillage with mineral 48 fertilizer and CTC is conventional tillage with cattle manure.

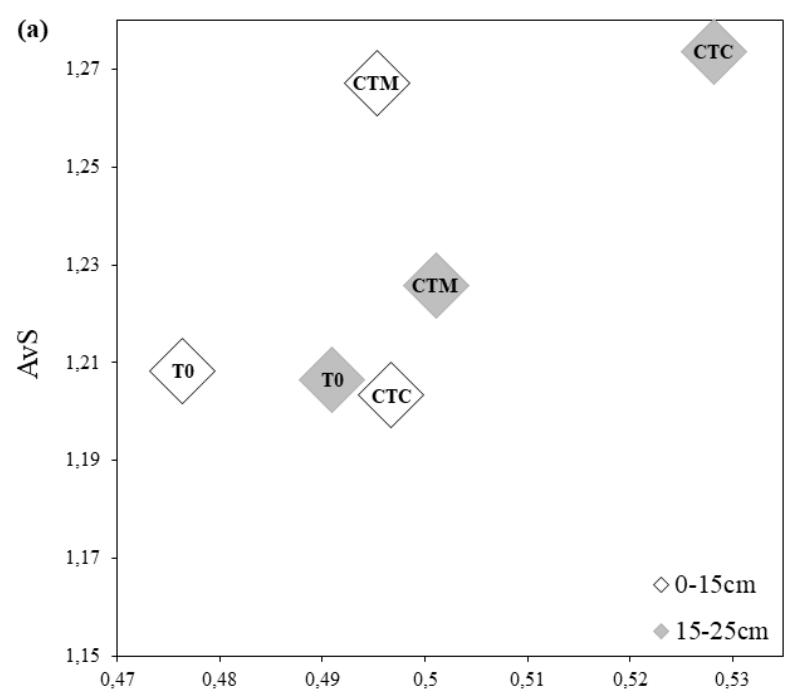

Intercept $/ \mathrm{cm}^{3} \mathrm{~cm}^{-3}$

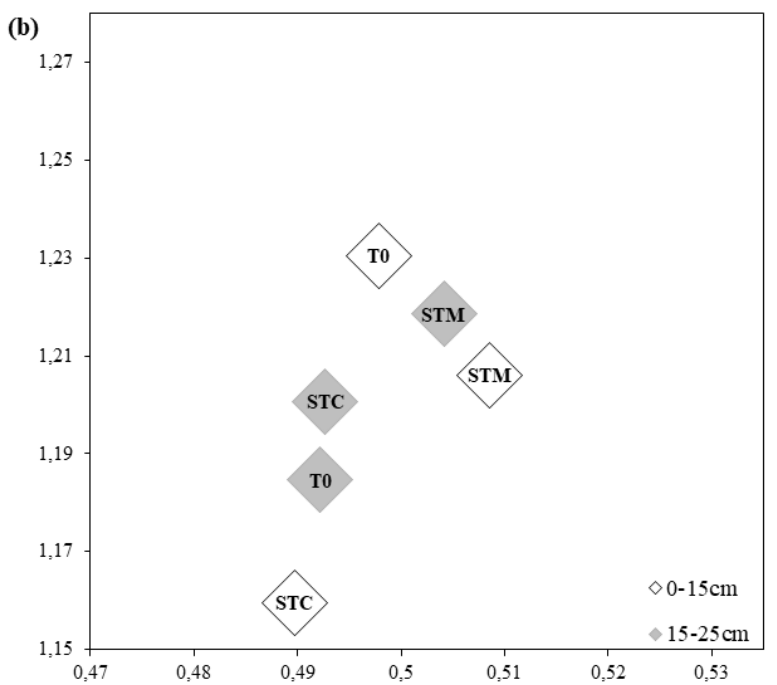

Intercept $/ \mathrm{cm}^{3} \mathrm{~cm}^{-3}$

49 
2 Results of two-way ANOVA with depth and fertilization as fixed effects on soil organic carbon content and bulk density under conventional and

3 shallow tillage.

\begin{tabular}{|c|c|c|c|c|c|c|c|c|c|}
\hline \multirow{2}{*}{$\begin{array}{c}\text { Source of } \\
\text { variation }\end{array}$} & \multirow{2}{*}{$\begin{array}{l}\text { Degrees of } \\
\text { freedom }\end{array}$} & \multicolumn{4}{|c|}{ Soil organic carbon content } & \multicolumn{4}{|c|}{ Bulk density } \\
\hline & & $\begin{array}{l}\text { Sum of } \\
\text { squares }\end{array}$ & $\begin{array}{c}\text { Mean } \\
\text { squares }\end{array}$ & F ratio & $P$ & $\begin{array}{l}\text { Sum of } \\
\text { squares }\end{array}$ & Mean squares & $F$ ratio & $P$ \\
\hline & \multicolumn{9}{|c|}{ Conventional tillage (CT) } \\
\hline Depth & 1 & 2.574 & 2.5742 & 10.323 & 0.0048 & 0.002558 & 0.002558 & 1.704 & 0.20821 \\
\hline Fertilizer & 2 & 1.14 & 0.5701 & 2.286 & 0.1304 & 0.023558 & 0.011779 & 7.847 & 0.00354 \\
\hline $\mathrm{D} * \mathrm{~F}$ & 2 & 0.13 & 0.0651 & 0.261 & 0.7732 & 0.000049 & 0.000024 & 0.016 & 0.98396 \\
\hline Residuals & 18 & 4.488 & 0.2494 & & & 0.02702 & 0.001501 & & \\
\hline Total & 23 & 8.332 & 3.4588 & & & 0.053185 & 0.015862 & & \\
\hline & \multicolumn{9}{|c|}{ Shallow tillage (ST) } \\
\hline Depth & 1 & 9.375 & 9.375 & 84.144 & $3.31 \mathrm{E}-08$ & 0.00151 & 0.001513 & 0.857 & 0.367 \\
\hline Fertilizer & 2 & 1.241 & 0.62 & 5.568 & 0.0131 & 0.00683 & 0.003414 & 1.934 & 0.173 \\
\hline $\mathrm{D} * \mathrm{~F}$ & 2 & 5.501 & 2.75 & 24.686 & $6.94 \mathrm{E}-06$ & 0.00462 & 0.002311 & 1.309 & 0.294 \\
\hline Residuals & 18 & 2.005 & 0.111 & & & 0.03177 & 0.001765 & & \\
\hline Total & 23 & 18.122 & 12.856 & & & 0.04473 & 0.009003 & & \\
\hline
\end{tabular}

4 
Table 2

8 The effect of agricultural practices on soil bulk density and soil organic carbon content at depths of $0-15 \mathrm{~cm}$ and $15-25 \mathrm{~cm}$, compared to the

9 initial state (T0). The T0 values are averaged for all 6 plots, while the values for each treatment are averaged for its 3 plots.

\begin{tabular}{c|c|c|c|cc}
\hline \multirow{2}{*}{} & \multicolumn{2}{|c|}{ Conventional tillage } & \multicolumn{2}{c}{ Shallow tillage } \\
\cline { 2 - 5 } & T0 & CTM & CTC & T0 & STM \\
\hline
\end{tabular}

Soil organic carbon content $\left(\mathrm{g} \mathrm{kg}^{-1}\right)$

\begin{tabular}{l|l|ll|l|ll}
$0-15 \mathrm{~cm}$ & $11.0(0.2)^{\mathrm{a}, \mathrm{a}}$ & $10.8(0.2)^{\mathrm{a}, \mathrm{a}}$ & $11.5(0.3)^{\mathrm{a}, \mathrm{a}}$ & $10.4(0.2)^{\mathrm{c}, \mathrm{a}}$ & $11.3(0.2)^{\mathrm{b}, \mathrm{a}}$ & $12.1(0.2)^{\mathrm{a}, \mathrm{a}}$ \\
$15-25 \mathrm{~cm}$ & $10.3(0.3)^{\mathrm{a}, \mathrm{b}}$ & $10.4(0.2)^{\mathrm{a}, \mathrm{a}}$ & $10.8(0.3)^{\mathrm{a}, \mathrm{a}}$ & $10.1(0.1)^{\mathrm{a}, \mathrm{a}}$ & $9.4(0.2)^{\mathrm{b}, \mathrm{b}}$ & $9.6(0.1)^{\mathrm{b}, \mathrm{b}}$ \\
\hline
\end{tabular}

\begin{tabular}{l|l|ll|l|ll} 
Bulk density & & & \\
$0-15 \mathrm{~cm}$ & $1.56(0.02)^{\mathrm{a}, \mathrm{a}}$ & $1.62(0.01)^{\mathrm{a}, \mathrm{a}}$ & $1.62(0.02)^{\mathrm{a}, \mathrm{a}}$ & $1.58(0.01)^{\mathrm{a}, \mathrm{a}}$ & $1.61(0.02)^{\mathrm{a}, \mathrm{a}}$ & $1.59(0.03)^{\mathrm{a}, \mathrm{a}}$ \\
$15-25 \mathrm{~cm}$ & $1.54(0.02)^{\mathrm{a}, \mathrm{a}}$ & $1.60(0.02)^{\mathrm{a}, \mathrm{a}}$ & $1.59(0.00)^{\mathrm{a}, \mathrm{a}}$ & $1.55(0.02)^{\mathrm{a}, \mathrm{a}}$ & $1.57(0.02)^{\mathrm{a}, \mathrm{a}}$ & $1.62(0.04)^{\mathrm{a}, \mathrm{a}}$ \\
\hline
\end{tabular}

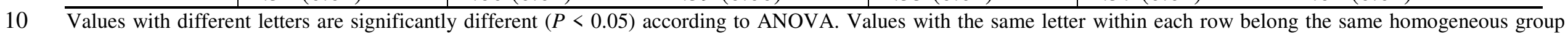

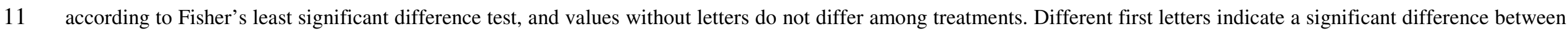
treatments, whereas different second letters indicate a significant difference between depths for the same treatment. Standard errors of means are indicated in parentheses.

STM is shallow tillage with mineral fertilizer; STC is shallow tillage with cattle manure; CTM is conventional tillage with mineral fertilizer and CTC is conventional tillage 14 with cattle manure. 
The effects of depth and fertilization treatments on soil water content (SWC) and water holding capacity (WHC) at three pressure heads (near saturation $(-3.2 \mathrm{kPa})$, field capacity $(-31.6 \mathrm{kPa})$ and permanent wilting point $(-1585 \mathrm{kPa}))$, compared to the initial state (T0) under conventional and shallow tillage.

\begin{tabular}{|c|c|c|c|c|c|c|}
\hline \multirow{2}{*}{$\begin{array}{l}\text { Matric potential } \\
(\mathrm{kPa})\end{array}$} & \multicolumn{3}{|c|}{ Conventional tillage (CT) } & \multicolumn{3}{|c|}{ Shallow tillage (ST) } \\
\hline & T0 & CTM & CTC & T0 & STM & STC \\
\hline \multicolumn{7}{|c|}{$0-15 \mathrm{~cm}$} \\
\hline \multicolumn{7}{|l|}{$\operatorname{SWC}\left(\mathrm{cm}^{3} \mathrm{~cm}^{-3}\right)$} \\
\hline-3.2 & $0.432(0.005)^{\mathrm{a}}$ & $0.446(0.011)^{\mathrm{a}}$ & $0.439(0.009)^{\mathrm{a}}$ & $0.432(0.004)^{\mathrm{a}}$ & $0.448(0.010)^{\mathrm{a}}$ & $0.440(0.011)^{a}$ \\
\hline-31.6 & $0.376(0.008)^{\mathrm{a}}$ & $0.383(0.008)^{\mathrm{a}}$ & $0.391(0.006) a$ & $0.373(0.006)^{\mathrm{a}}$ & $0.369(0.006)^{\mathrm{a}}$ & $0.380(0.012)^{a}$ \\
\hline-1585 & $0.114(0.001)^{b}$ & $0.122(0.002)^{\mathrm{a}}$ & $0.114(0.002)^{b}$ & $0.113(0.001)^{\mathrm{ab}}$ & $0.110(0.004)^{b}$ & $0.121(0.004)^{a}$ \\
\hline $\mathrm{WHC}(\mathrm{mm}) *$ & & & & & & \\
\hline-31.6 to -1585 & $26.2(0.8)^{\mathrm{a}}$ & $26.1(0.8)^{\mathrm{a}}$ & $27.6(0.7)^{\mathrm{a}}$ & $26.0(0.7)^{a}$ & $25.9(0.7)^{\mathrm{a}}$ & $26.0(1.4)^{\mathrm{a}}$ \\
\hline \multicolumn{7}{|c|}{$15-25 \mathrm{~cm}$} \\
\hline $\operatorname{SWC}\left(\mathrm{cm}^{3} \mathrm{~cm}^{-3}\right)$ & & & & & & \\
\hline-3.2 & $0.430(0.006)^{\mathrm{b}}$ & $0.442(0.011)^{\mathrm{b}}$ & $0.470(0.008)^{\mathrm{a}}$ & $0.431(0.005)^{\mathrm{a}}$ & $0.450(0.011)^{\mathrm{a}}$ & $0.429(0.012)^{a}$ \\
\hline-31.6 & $0.362(0.008)^{b}$ & $0.378(0.008)^{b}$ & $0.415(0.004)^{\mathrm{a}}$ & $0.370(0.007)^{\mathrm{a}}$ & $0.366(0.008)^{\mathrm{a}}$ & $0.355(0.006)^{2}$ \\
\hline-1585 & $0.115(0.001)^{\mathrm{a}}$ & $0.121(0.005)^{\mathrm{a}}$ & $0.117(0.002)^{\mathrm{a}}$ & $0.116(0.002)^{\mathrm{a}}$ & $0.107(0.001)^{b}$ & $0.120(0.004)^{a}$ \\
\hline WHC $(\mathrm{mm})^{*}$ & & & & & & \\
\hline-31.6 to -1585 & $24.8(0.9)^{\mathrm{b}}$ & $25.6(0.8)^{b}$ & $29.8(0.4)^{\mathrm{a}}$ & $25.4(0.8)^{\mathrm{ab}}$ & $25.9(0.8)^{\mathrm{a}}$ & $23.5(0.7)^{b}$ \\
\hline
\end{tabular}

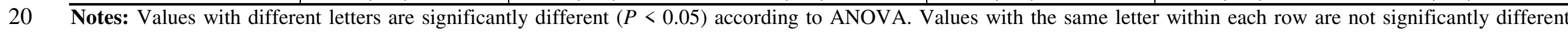
according to the probability of mean differences at $\alpha=0.05$ with Fisher's least significant difference test. Standard errors of means are indicated in parentheses. STM is cattle manure. 
The absolute value of the slope and the intercept of the relationship between the soil water spectral index and soil water content for soil samples

from two depths at the initial state (T0) and under four treatments: STM, shallow tillage with mineral fertilizer; STC, shallow tillage with cattle manure; CTM, conventional tillage with mineral fertilizer and CTC, conventional tillage with cattle manure.

\begin{tabular}{|c|c|c|c|c|c|}
\hline & Treatment & $\begin{array}{c}\text { Intercept (Se) } \\
\mathrm{cm}^{3} \mathrm{~cm}^{-3}\end{array}$ & $\operatorname{AvS}(\mathrm{Se})$ & $\overline{p \text {-value }}$ & $R^{2}$ \\
\hline \multicolumn{6}{|l|}{$0-15 \mathrm{~cm}$} \\
\hline \multirow{4}{*}{ CT } & T0 & $0.476(0.007)$ & $1.21(0.02)$ & $5.32 \mathrm{E}-12$ & 98.8 \\
\hline & СТM & $0.495(0.015)$ & $1.27(0.04)$ & $7.80 \mathrm{E}-11$ & 99.6 \\
\hline & CTC & $0.497(0.011)$ & $1.20(0.02)$ & $2.07 \mathrm{E}-11$ & 99.7 \\
\hline & T0 & $0.498(0.006)$ & $1.23(0.02)$ & $3.03 \mathrm{E}-12$ & 99 \\
\hline \multirow[t]{2}{*}{ ST } & STM & $0.509(0.014)$ & $1.21(0.03)$ & $1.79 \mathrm{E}-09$ & 99.1 \\
\hline & STC & $0.490(0.011)$ & $1.16(0.02)$ & $3.62 \mathrm{E}-11$ & 99.7 \\
\hline \multicolumn{6}{|l|}{$15-25 \mathrm{~cm}$} \\
\hline \multirow{3}{*}{ CT } & T0 & $0.491(0.008)$ & $1.21(0.02)$ & $3.42 \mathrm{E}-13$ & 99 \\
\hline & CTM & $0.501(0.012)$ & $1.23(0.03)$ & 2.93E-09 & 99.8 \\
\hline & CTC & $0.528(0.006)$ & $1.27(0.01)$ & $3.25 \mathrm{E}-10$ & 99.7 \\
\hline \multirow{3}{*}{ ST } & T0 & $0.492(0.007)$ & $1.18(0.02)$ & $5.41 \mathrm{E}-13$ & 99 \\
\hline & STM & $0.504(0.012)$ & $1.22(0.03)$ & $6.34 \mathrm{E}-12$ & 99 \\
\hline & STC & $0.493(0.017)$ & $1.20(0.04)$ & $1.71 \mathrm{E}-11$ & 99.4 \\
\hline
\end{tabular}


Results of two-way ANOVA of the intercept and absolute value of the slope (AvS) of the relationship between the soil water spectral index and soil water content with depth and fertilization as fixed effects under mineral and organic fertilization.

\begin{tabular}{|c|c|c|c|c|c|c|c|c|c|}
\hline \multirow{2}{*}{$\begin{array}{l}\text { Source of } \\
\text { variation }\end{array}$} & \multirow{2}{*}{$\begin{array}{l}\text { Degrees of } \\
\text { freedom }\end{array}$} & \multicolumn{4}{|c|}{ Intercept $\left(\mathrm{cm}^{3} \mathrm{~cm}^{-3}\right)$} & \multicolumn{4}{|c|}{ AvS } \\
\hline & & $\begin{array}{l}\text { Sum of } \\
\text { squares }\end{array}$ & Mean squares & $F$ ratio & $P$ & $\begin{array}{l}\text { Sum of } \\
\text { squares }\end{array}$ & $\begin{array}{c}\text { Mean } \\
\text { squares }\end{array}$ & $F$ ratio & $P$ \\
\hline & \multicolumn{9}{|c|}{ Conventional tillage } \\
\hline Depth & 1 & 0.00598 & 0.005981 & 4.512 & 0.0368 & 0.0012 & 0.00118 & 0.118 & 0.732 \\
\hline Fertilizer & 2 & 0.0121 & 0.006048 & 4.563 & 0.0134 & 0.0261 & 0.013074 & 1.311 & 0.275 \\
\hline $\mathrm{D} * \mathrm{~F}$ & 2 & 0.00205 & 0.001026 & 0.774 & 0.4646 & 0.0389 & 0.019449 & 1.95 & 0.149 \\
\hline Residuals & 78 & 0.10339 & 0.001326 & & & 0.7779 & 0.009973 & & \\
\hline Total & 83 & 0.12352 & 0.014381 & & & 0.8441 & 0.043676 & & \\
\hline & \multicolumn{9}{|c|}{ Shallow tillage } \\
\hline Depth & 1 & 0.00017 & 0.0001701 & 0.106 & $7.46 \mathrm{E}-01$ & 0.0004 & 0.000399 & 0.046 & 0.831 \\
\hline Fertilizer & 2 & 0.00306 & 0.0015315 & 0.952 & 0.39 & 0.0151 & 0.007552 & 0.867 & 0.424 \\
\hline $\mathrm{D} * \mathrm{~F}$ & 2 & 0.00029 & 0.0001433 & 0.089 & $9.15 \mathrm{E}-01$ & 0.0297 & 0.01485 & 1.706 & 0.188 \\
\hline Residuals & 78 & 0.12549 & 0.0016088 & & & 0.679 & 0.008705 & & \\
\hline Total & 83 & 0.12901 & 0.0034537 & & & 0.7242 & 0.031506 & & \\
\hline
\end{tabular}


Table 1

Pearson correlation matrix of the absolute value of the slope (AvS) and intercept of the relationship between the soil water spectral index and soil water content and soil properties [soil organic carbon (SOC) content, bulk density (BD), water holding capacity (WHC), and the Dexter index of soil physical quality $\left.\left(\mathrm{S}_{\text {Dexter }}\right)\right]$.

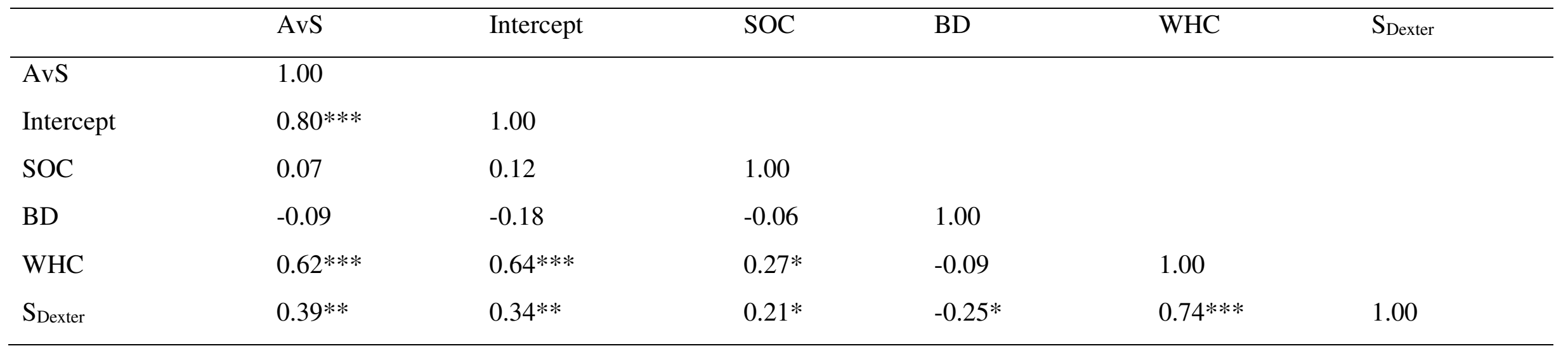

* significant at $P<0.001 ;{ }^{* *}$ significant at $P<0.01 ;{ }^{*}$ significant at $P<0.05$ 